\title{
REVIEW
}

\section{Endogenous galectins and the control of the host inflammatory response}

\author{
Lucy V Norling, Mauro Perretti and Dianne Cooper \\ Barts and The London School of Medicine, The William Harvey Research Institute, Centre for Biochemical Pharmacology, Queen Mary University of London, \\ Charterhouse Square, London EC1M 6BQ, UK \\ (Correspondence should be addressed to D Cooper; Email: d.cooper@qmul.ac.uk)
}

\begin{abstract}
A new era of research is being devoted to deciphering endogenous mediators and mechanisms that are in place to resolve the inflammatory response. Accruing evidence indicates that galectins fall into this category of immunoregulatory mediators signifying their use as prospective novel anti-inflammatory agents. The focus of this review is to depict the immunoregulatory bioactivities of three members of the galectin superfamily, Galectin (Gal)-1, Gal-3 and Gal-9.
\end{abstract}

Emphasis is given to the studies investigating the properties of these endogenous lectins. Gal-1, Gal-3 and Gal-9 are emerging as pertinent players in the modulation of acute and chronic inflammatory diseases, autoimmunity and cancer, and thus being increasingly recognised as molecular targets for innovative drug discovery.

Journal of Endocrinology (2009) 201, 169-184

\section{Galectins - generalities; biochemistry; cell sources}

Members of the galectin family of proteins are classified by their ability to bind $\beta$-galactosides and by a conserved sequence of approximately 130 amino acids within their carbohydrate recognition domains (CRDs) (Barondes et al. 1994). To date, 15 members have been identified, which based on their structure and number of CRDs, are subdivided into one of three groups (Fig. 1). The prototype galectins contain a single CRD and can form homodimers, whereas the tandem-repeat galectins consist of two non-identical CRDs joined by a short peptide, and the unique chimeratype galectin-3 contains a single CRD with an extended N-terminus (Barondes et al. 1994).

In contrast to the selectins, galectin binding to carbohydrates is calcium independent (Hughes 2001). Galectins bind to $N$-acetyllactosamine (Gal $\beta 1,3 \mathrm{GlcNAc}$ or Gal $\beta 1$, 4GlcNAc), a common disaccharide found on many $N$ - or O-linked glycans (Elola et al. 2005). The mere presence of galactose residues in glycoconjugates is not sufficient to promote high-affinity binding, and a fine specificity in binding is evident by the limited set of glycoconjugates to which they bind. In addition, many galectins can bind to carbohydrates in a bivalent or multivalent style, allowing cross-linking and redistribution of cell surface glycoproteins (Yang et al. 2008). Galectins can also bind their ligands in a carbohydrate-independent manner. This is often the case intracellularly, where ligand binding occurs predominantly through protein-protein interactions (see Liu et al. 2002 for review). An intriguing aspect of galectin biology is that, although these proteins lack a signal peptide and therefore do not exit the cell via the classical secretory pathway, they are known to be actively secreted from cells (Cho \& Cummings 1995). Various models for exportation of the different members of the galectin family have been proposed (reviewed by Elola et al. 2007).

Galectins have been isolated from a number of species ranging from vertebrates to sponges, suggesting that they perform essential roles in basic cellular function (Cooper \& Barondes 1999, Houzelstein et al. 2004). Nuclear localisation of Gal-1 and Gal-3 is possibly connected with a role in the regulation of pre-mRNA splicing (Vyakarnam et al. 1997, Wang et al. 2004), while extracellular location indicates functions in cell-cell and cell-matrix interactions (Hughes 2001, reviewed by Elola et al. (2007)). A diverse range of biological functions involved in immune and inflammatory responses and tumour development have been reported for galectins over the last decade including roles in cellular adhesion, migration and survival (see Elola et al. 2007, Yang et al. 2008 for recent reviews).

Within the immune system, Gal-1 is specifically localised in lymphoid organs (Baum et al. 1995b), T cells (Blaser et al. 1998, Fuertes et al. 2004), activated macrophages (Rabinovich et al. 1998) and endothelial cells (Lotan et al. 

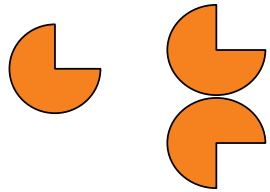

Prototype galectin

e.g. galectin-1

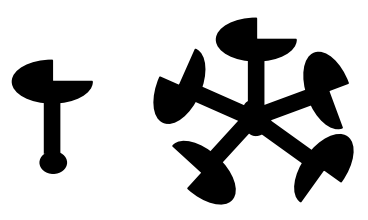

Chimera type:

galectin-3

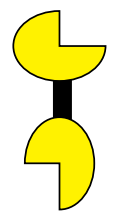

Tandem repeat e.g. galectin-9

Figure 1 Subtypes of the galectin family. Galectins can be divided into three subtypes based on their structure. Schematic examples of prototype galectins: Gal-1 has one carbohydrate recognition domain and can function as a monomer or homodimer; Gal-3 is the only chimeric galectin with a carbohydrate recognition domain and an extended $\mathrm{N}$-terminus through which it can form pentamers; tandem-repeat galectins (e.g. Gal-9) consist of two non-identical CRDs joined by a short peptide.

1994, Baum et al. 1995b). Furthermore, expression of Gal-1 in endothelial cells can be modulated by several inflammatory agents, supporting its role in inflammatory incidences (Baum et al. 1995b). Gal-3 is expressed by virtually all immune cell types, including endothelial cells, lymphocytes (Lotan et al. 1994, Baum et al. 1995b), neutrophils (Truong et al. 1993), monocytes and macrophages (Liu et al. 1995), mast cells (Craig et al. 1995) and dendritic cells (Flotte et al. 1983). Gal-3 expression has been found to be increased in neutrophils upon adhesion to the endothelium (Gil et al. 2006b), which also coincided with a relocalisation of Gal-3 to the plasma membrane in endothelial cells (Gil et al. 2006b). Such relocalisation to the membrane of endothelial cells has also been observed upon adhesion of tumour cells (Glinsky et al. 2001). Gal-9 is also distributed in certain cells fundamental to the inflammatory response: endothelial cells (Imaizumi et al. 2002), T cells (Matsumoto et al. 1998) and fibroblasts (Asakura et al. 2002). Knockout mice have been generated for these three galectins and have provided a tool for researchers to investigate their roles under inflammatory conditions. Table 1 outlines the phenotypes of these mice.

Finally, the keen reader could refer to recent excellent reviews on galectins' biology (Elola et al. 2007, Yang et al. 2008). Here, we will dwell on recent understanding of the impact of galectins, mainly Gal-1, Gal-3 and Gal-9, on the immune response.

\section{Inflammation and anti-inflammation: a balancing act!}

During an inflammatory response, individuals experience the cardinal signs of inflammation; pain, fever, redness and swelling and in chronic conditions, this can ultimately lead to loss of function. These symptoms are a result of a complex set of microscopic events that take place both at the site of inflammation and systemically. Inflammatory reactions are generally protective and serve to maintain tissue homeostasis, although if uncontrolled they become deleterious to the host.
In nearly all cases, the fundamental cause of tissue damage is leukocyte accumulation. Leukocyte recruitment in both homeostatic and inflammatory situations is a highly regulated process that requires specific and sequential molecular interactions between leukocytes and the vascular endothelium. Insights into the cellular and molecular processes involved in each step of the cascade have been provided by a range of experimental approaches performed both in vitro and in vivo. These include antibody inhibition studies, static adhesion assays, parallel-plate flow chamber models, as well as using intravital microscopy of small animals to visualise live interactions of leukocytes with the vessel wall. These studies have helped to elucidate that i) initial leukocyte-endothelial interactions (capture and rolling) are instigated primarily by a family of molecules called selectins along with their oligosaccharide ligands, and ii) firm adhesion and transmigration are mediated by leukocyte integrins interacting with the endothelial immunoglobulin superfamily of adhesion molecules.

The reparative and resolving phase of inflammation is not merely a passive process as once believed, but actively takes place. While an array of pro-inflammatory mediators exist to initiate inflammation, a repertoire of anti-inflammatory mediators and mechanisms operate in the host to promote and control the phase of resolution, by inhibiting leukocyte migration and promoting clearance of inflammatory cells (Gilroy et al. 2004, Serhan et al. 2007). Accumulating evidence indicates that galectins fall into this category of immunoregulatory mediators signifying their potential use as novel anti-inflammatory agents. Their actions on cells of the vascular system are outlined in Fig. 2. We will summarise now the current knowledge on the properties of endogenous Gal1, Gal-3 and Gal-9 as evidenced from integrated system biology analyses.

\section{Anti-inflammatory and pro-inflammatory galectins}

Generally, Gal-1 is known to bestow a range of antiinflammatory effects on various cells types, inhibiting cell trafficking, inducing apoptosis and modulating the release of 
Table 1 Phenotype of galectin null mice

\begin{tabular}{|c|c|c|c|}
\hline & Disease model/inflammogen & Phenotype & References \\
\hline \multirow[t]{3}{*}{ Galectin-1 } & Peritonitis & Increased neutrophil recruitment & www.functionalglycomics.org/ \\
\hline & $\begin{array}{l}\text { Experimental allergic } \\
\text { encephalomyelitis }\end{array}$ & $\begin{array}{l}\text { Increased susceptibility, 'hyper' Th1 and Th17 } \\
\text { responses }\end{array}$ & Toscano et al. (2007) \\
\hline & Delayed-type hypersensitivity & $\begin{array}{l}\text { Increased oedema and lymphocyte infiltration } \\
\text { to the inflamed paw }\end{array}$ & Norling et al. (2008) \\
\hline & Peritonitis & Reduced neutrophil recruitment & Colnot et al. $(1998 a, b)$ \\
\hline & Endotoxic shock & $\begin{array}{l}\text { Increased susceptibility, with increased production } \\
\text { of pro-inflammatory cytokines and NO }\end{array}$ & Li et al. (2008) \\
\hline & Bacterial infection & $\begin{array}{l}\text { Reduced neutrophil recruitment to the lungs } \\
\text { following } S \text {. pneumoniae infection }\end{array}$ & Nieminen et al. (2008) \\
\hline & Prion infection & $\begin{array}{l}\text { Increased survival, following intracerebral and } \\
\text { peripheral scrapie infection }\end{array}$ & Mok et al. (2007) \\
\hline \multirow[t]{2}{*}{ Galectin-9 } & Arthritis & $\begin{array}{l}\text { Enhanced incidence, increased numbers of } \\
\text { TIM- } 3^{+} \mathrm{CD} 4^{+} \mathrm{T} \text { cells }\end{array}$ & Seki et al. (2008) \\
\hline & Endotoxic shock & Increased mortality & Tsuboi et al. (2007) \\
\hline
\end{tabular}

mediators. By contrast, Gal-3 is widely pro-inflammatory provoking leukocyte activation, whereas Gal-9 is most commonly known for its chemotactic activity towards eosinophils, and has more recently been revealed as a negative regulator of Th1 cells. Specific effects of Gal-1, -3 and -9 will be addressed in succession.

\section{Actions of exogenous galectin-1}

Application of exogenous Gal-1 (LGALS1) has shown immunosuppressive and anti-inflammatory efficacy in various experimental models of inflammation and autoimmunity, including colitis (Santucci et al. 2003), concanavalin A-induced hepatitis (Santucci et al. 2000), arthritis (Rabinovich et al. 1999b), diabetes (Perone et al. 2006), experimental autoimmune encephalomyelitis (EAE) (Offner et al. 1990), myasthenia gravis (Levi et al. 1983) and uveitis (Toscano et al. 2006).

Using gene or protein therapy strategies, Gal-1 has been shown to attenuate paw swelling, clinical score and histopathological symptoms of collagen-induced arthritis (Rabinovich et al. 1999b). Investigation into the molecular mechanisms involved in this process revealed that Gal-1 treatment increases T-cell susceptibility to activation-induced apoptosis and promotes a shift from a T-helper cell type 1 (Th1) to a Th2-polarised immune response, characterised by an increase in IL5 and a concomitant reduction in IL2 and IFNG levels (Rabinovich et al. 1999b). In a model of hepatitis, Gal-1 pre-treatment (40 $\mu \mathrm{g} ; 30 \mathrm{~min})$ prevented liver injury and tissue infiltration of $\mathrm{T}$ cells. These effects were associated with apoptosis of activated $\mathrm{T}$ cells and inhibition of concanavalin A-induced TNF and IFNG secretion (Santucci et al. 2000). Indeed, several studies have implicated Gal-1 to modulate the $\mathrm{T}$ cell cytokine repertoire. Low concentrations of Gal-1 (10-100 nM) can inhibit IFNG and TNF production by IL2-activated $\mathrm{T}$ cells in vitro (Rabinovich et al. 1999a) and production of cytokines such as TNF, IL1B, IL12 and IFNG in vivo (Santucci et al. 2003). Additionally, treatment of T cells with Gal-1 is associated with increased mRNA and protein expression of IL10 (van der Leij et al. 2004), and an inhibition of IL2 secretion (van der Leij et al. 2007).

The anti-inflammatory and immunosuppressive effects of Gal-1 in models of $\mathrm{T}$ cell-driven pathologies are often deemed to be due to the pro-apoptotic nature of this lectin, and thus these studies are complemented by a much larger series of in vitro studies. Regulation of cell death by apoptosis is vital for normal cell turnover and maintenance of homeostasis. Apoptosis occurs during $\mathrm{T}$ cell maturation in the thymus to remove potentially autoaggressive cells, as failure to do so may lead to various autoimmune diseases if these cells escape to the periphery. In relation to this, early studies showed Gal-1 synthesis by thymic epithelial cells caused apoptosis of immature thymocytes (Baum et al. 1995a). Together, these results suggest a functional role of Gal-1 in the process of positive and/or negative selection in the thymus (Perillo et al. 1997). Indeed, current investigations have highlighted that Gal-1 can selectively promote negative selection and oppose positive selection by reducing and enhancing the TCR signalling threshold respectively (Liu et al. 2008). In addition, activated mature $\mathrm{T}$ cells undergo apoptosis to prevent an overactive immune response. 


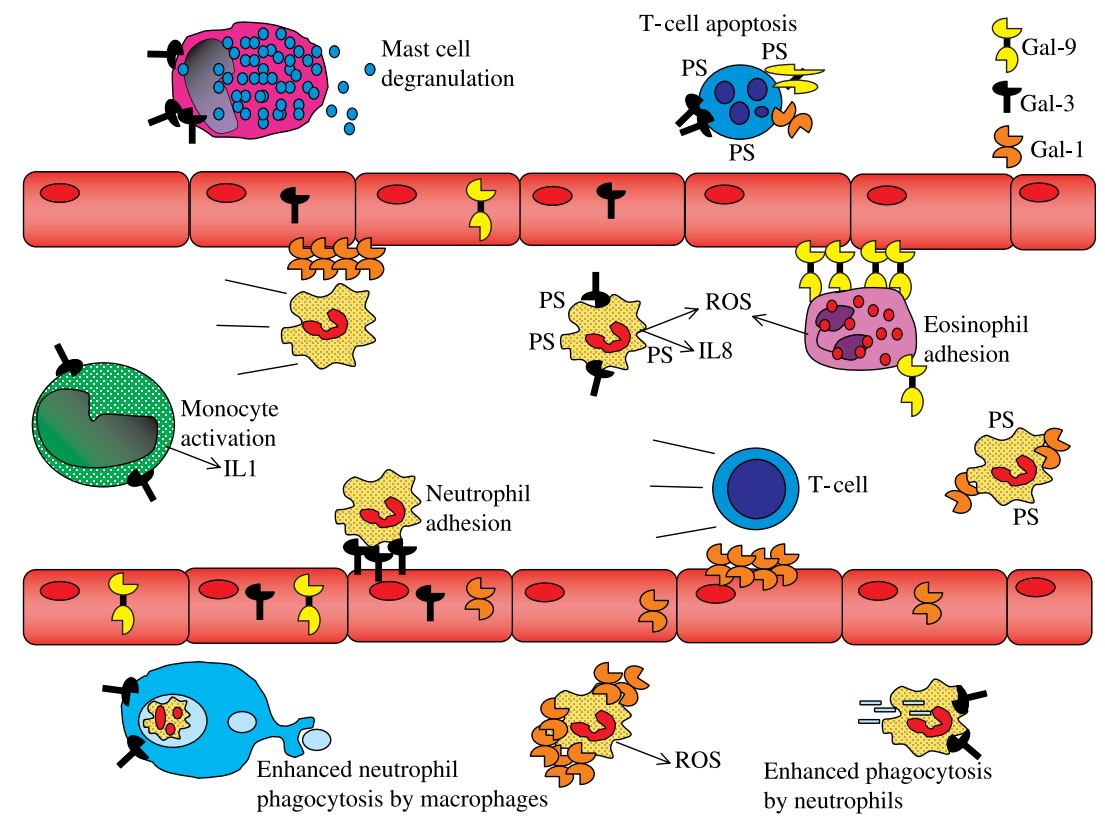

Figure 2 Events controlled by Gal-1, Gal-3 and Gal-9 on the blood and vascular cells during inflammation. Gal-1, Gal-3 and Gal-9 have been reported to have numerous effects on the cells of the vascular system. Gal-1 has been reported to inhibit PMN adhesion and T-cell adhesion and emigration, while Gal-3 promotes PMN adhesion both to endothelial cells and components of the extracellular matrix. Gal-9 has been found to promote eosinophil recruitment. All three galectins induce T-cell apoptosis, while Gal-1 and Gal-3 also induce phosphatidylserine exposure on PMN in the absence of apoptosis. The pro-inflammatory actions of Gal-3 are further substantiated by its ability to induce IL1 production by monocytes, mast cell degranulation and ROS and IL8 generation by PMN. Gal-9 has also been found to induce ROS generation by eosinophils. Gal-1 appears to have concentrationdependent effects; at high concentrations, Gal-1 induces ROS generation by exudated PMN. Gal-3 may also play a role in the resolution of inflammation by enhancing phagocytosis of apoptotic PMN by macrophages and phagocytosis of bacteria by PMN.

Various studies have indicated that exogenous Gal-1 induces apoptosis of mature and activated, but not resting, T cells (Blaser et al. 1998, Rabinovich et al. 1998), by specific recognition of the differentially glycosylated CD45RO isoform of PTPRC displayed by memory $\mathrm{T}$ cells (Perillo et al. 1995). These results may well explain the in vivo efficacy of Gal-1; however, it must be noted that relatively high concentrations $(10 \mu \mathrm{M})$ are often used to attain these effects, and that the apoptotic effect is dependent on cross-linking specific cell surface glycoproteins (Symons et al. 2000). Whether Gal-1 levels could be so high in vivo is questionable and further studies are required to elucidate the mode of Gal-1 actions, although it could be postulated that these concentrations might be reached within specific intracellular and paracellular microenvironments.

Aside from its apoptotic role, it has been documented that Gal-1 also exerts its anti-inflammatory effects via apoptoticindependent mechanisms. At concentrations below its apoptotic threshold (10-100 nM), Gal-1 inhibits T-cell adhesion to extracellular matrix (ECM) glycoproteins (Rabinovich et al. 1999a) and TNF and IFNG secretion by activated T cells (Rabinovich et al. 1999b).
Interestingly, Gal-1 also plays a pivotal role in the innate immune response-promoting resolution of acute inflammation. First, experimental evidence was seen in a rat model of paw oedema induced by bee venom phospholipase $A_{2}$ (Rabinovich et al. 2000). Local administration of Gal-1 repressed the inflammatory response in a dosedependent manner. This effect was not abrogated when Gal-1 was pre-incubated with $100 \mathrm{mM}$ lactose, but could be reversed with Gal-1 anti-serum, showing a specific yet carbohydrate-independent effect. Immunohistochemical assessment of the inflamed paws showed a dramatic reduction in PMN infiltration, degranulated mast cells and overall tissue damage with a $30 \mathrm{~min}$ pre-treatment of Gal-1. To investigate the mechanism of its antiinflammatory properties, tests were performed in vitro on LPS-stimulated macrophages, and showed that Gal-1 inhibits arachadonic acid and $\mathrm{PGE}_{2}$ secretion, in a dose-dependent and carbohydrate-independent fashion (Rabinovich et al. 2000). Further investigations to elucidate the antiinflammatory activities of Gal-1 on activated rat peritoneal macrophages showed that this protein inhibits inducible nitric oxide synthase expression and potentiates the 
arginase pathway of L-arginine metabolism, thus inducing an 'alternative activation' of these macrophages (Correa et al. 2003).

Unlike its effects on $\mathrm{T}$ cells, Gal-1 does not induce neutrophil apoptosis, although it does cause exposure of phosphatidylserine on the cell membrane, which significantly promotes phagocytosis of apoptotic neutrophils by mouse macrophages (Dias-Baruffi et al. 2003). This study highlights an important facet of Gal-1 in leukocyte turnover, hence possessing the ability to aid in the resolution of inflammation.

Not all of Gal-1s actions are anti-inflammatory, at high concentrations ( $\geq 40 \mathrm{uM}$ range), it activates the $\operatorname{NAD}(\mathrm{P}) \mathrm{H}$ oxidase and subsequently superoxide generation in extravasated (but not peripheral) neutrophils (Almkvist et al. 2002), indicating that the activated leukocyte might expose Gal-1 receptors. Moreover, a recent paper has revealed a unique function of Gal-1 as a platelet activator (Pacienza et al. 2008).

Research from our laboratory has shown that Gal-1 inhibits the initial interactions of PMNs with endothelial cells of the post-capillary venule in an experimental model of inflammation (La et al. 2003). Mice treated with a low dose $(0.3 \mu \mathrm{g}$ corresponding to $\sim 21 \mathrm{pmol}$ ) of hr-Gal-1 showed a potent reduction in the effect of IL1B on cell flux, cell adhesion and emigration of PMNs. In vitro assays further confirmed that incubation of PMNs with hr-Gal-1 inhibited IL8-induced PMN chemotaxis and transendothelial migration ( $\mathrm{La}$ et al. 2003). We have also demonstrated that incubation of PMNs with low concentrations of hr-Gal-1 (27-270 nM) results in a significant inhibition in their capture, rolling and adhesion on endothelial cells under conditions of shear stress (Cooper et al. 2008). Furthermore, the reverse effect is observed when Gal-1 protein levels are knocked down using small interference RNA (siRNA) in HUVEC, with a marked increase $(\sim 90 \%)$ in cell recruitment.

Of great interest, these effects could be mimicked also when peripheral lymphocytes were flown over the endothelial monolayers, both in terms of pharmacological effect of added hr-Gal-1 and physiological properties revealed when endothelial Gal-1 levels were markedly reduced with siRNA (Norling et al. 2008).

Collectively, these results are strongly suggestive that endothelial Gal-1 is present on the membrane to mitigate an overzealous recruitment of lymphocytes (Norling et al. 2008). Incidentally, this inhibitory effect is also evident in static conditions, where decreased lymphocyte transmigration was observed when endothelial Gal-1 was overexpressed in response to prostate cancer cell-conditioned media (He \& Baum 2006). This effect was not associated with cell death, and could be inhibited by antiserum to Gal-1. These findings illustrate a potent inhibitory action for exogenous Gal-1 on lymphocyte recruitment, an additional property for Gal-1 that may underscore its efficacy in models of immunemediated inflammation. Studies describing the actions of administration of recombinant Gal-1 in vivo are outlined in Table 2.

\section{Gal-1 and the in vivo immune response}

The exact role of Gal-1 with regards to inflammatory and immune functions in vivo is currently unclear as targeted disruption of the Gal-1 gene in knockout mice produces animals that develop normally and are viable and fertile. The absence of major inflammatory phenotypic abnormalities under physiological conditions suggests that other proteins may potentially compensate for Gal-1 (Poirier \& Robertson 1993). Utilisation of Gal-1 null mice has proved to be an important tool for assessing its function in immune responses, and has provided further evidence that this protein plays a key role in inflammation.

The functional relevance of endogenous Gal-1 was recently demonstrated in a model of peritonitis, whereby a 30 min pre-treatment of anti-Gal-1 serum prior to administration of carrageenin augmented the neutrophil influx into the peritoneum at $48 \mathrm{~h}$ (Gil et al. 2006a). It has also been documented on the Functional Glycomics Consortium that Gal-1 null mice display an increased neutrophil recruitment into the inflamed peritoneum $72 \mathrm{~h}$ post-injection with peptone (www.functionalglycomics.org/).

Using intravital microscopy of the mouse cremaster, an increase in leukocyte adhesion and emigration in Gal-1 null mice was observed following IL1B-induced inflammation (Cooper et al. 2008). Moreover, recent unpublished data from our laboratory visualising the PAF-inflamed cremaster demonstrated enhanced leukocyte emigration in Gal-1 null mice compared with controls during a $2 \mathrm{~h}$ time course, indicating that the heightened leukocyte infiltration in these null mice is not stimulus or tissue site specific. Short-term homing assays further implicate Gal-1 as a negative regulator of leukocyte recruitment during homeostatic and inflammatory conditions. Gal-1 null mice displayed a significant increase in the proportion of labelled splenocytes within the mesenteric lymph nodes under naive conditions. Under inflammatory conditions, increased numbers of methylated BSA-sensitised lymphocytes were recruited to the inflamed paw in Gal-1null mice compared with their WT counterparts, as assessed $5 \mathrm{~h}$ post-challenge (Norling et al. 2008). Altogether, we believe that endogenous Gal-1 acts as a break signal in counteracting the extent of leukocyte trafficking in the early stages of inflammation; its source and localisation is the endothelium, but it is yet unclear whether these effects result from a direct inhibition on the leukocyte or are indirectly determined by a non-genomic alteration of the phenotype of the endothelial cell.

Aside from its role in leukocyte recruitment, Gal-1 has recently been demonstrated as an important factor for angiogenesis. Current research has shown that knockdown of endothelial Gal-1, using specific antisense oligonucleotides, inhibits endothelial proliferation and migration (Thijssen et al. 2006). Additionally, Gal-1 null mice display impaired tumour progression due to decreased neovascularisation (Thijssen et al. 2006). In this respect, endothelial Gal-1 may be a novel way of targeting various cancers for 
Table 2 In vivo actions of exogenous galectins

\begin{tabular}{|c|c|c|c|c|}
\hline \multirow[b]{2}{*}{ Disease $\mathrm{model} / \mathrm{species}$} & Inflammogen & Treatment & Effect & \multirow[t]{2}{*}{ References } \\
\hline & & & & \\
\hline Paw oedema rat & Phospholipase $\mathrm{A}_{2}$ & $\begin{array}{l}\text { Pre-treatment of hr-Gal-1 } \\
\text { (30 min; 5-160 ng) or } \\
\text { co-injection (40-80 ng) } \\
\text { with PLA }\end{array}$ & $\begin{array}{l}\text { Inhibited oedema. Reduced } \\
\text { infiltration of PMN and } \\
\text { mast cell degranulation. }\end{array}$ & $\begin{array}{l}\text { Rabinovich } \\
\text { et al. (2000) }\end{array}$ \\
\hline Peritonitis mouse & IL1B & $\begin{array}{l}\text { Co-injection of hr-Gal-1 } \\
(0.3-3 \mu \mathrm{g}) \text { with IL1B }\end{array}$ & $\begin{array}{l}\text { Reduced PMN migration into } \\
\text { the peritoneum }\end{array}$ & La et al. (2003) \\
\hline Colitis mouse & $\begin{array}{l}\text { Trinitrobenzene } \\
\text { sulphonic acid }\end{array}$ & $\begin{array}{l}\text { Prophylactic: hr-Gal-1 } \\
(0.04-4 \mathrm{mg} / \mathrm{kg}) \text { daily i.v. } \\
\text { for } 7 \text { days. Therapeutic: } \\
\text { hr-Gal- } 1 \text { i.v. daily for } \\
7 \text { days, } 2 \text { weeks after } \\
\text { colitis induction }\end{array}$ & $\begin{array}{l}\text { Prevented/reverted wasting } \\
\text { syndrome. Inhibition of } \\
\text { pro-inflammatory cytokine } \\
\text { production (TNF, IL1B, } \\
\text { IL12, IFNG). }\end{array}$ & $\begin{array}{l}\text { Santucci } \\
\quad \text { et al. (2003) }\end{array}$ \\
\hline Hepatitis mouse & Concavalin A & $\begin{array}{l}\text { Pre-treatment of hr-Gal-1 } \\
\quad(30 \mathrm{~min} ; 5-40 \mu \mathrm{g})\end{array}$ & $\begin{array}{l}\text { Prevents liver injury. Inhibits } \\
\text { T-cell infiltration. Inhibition } \\
\text { of TNF and IFNG pro- } \\
\text { duction }\end{array}$ & $\begin{array}{l}\text { Santucci } \\
\quad \text { et al. (2000) }\end{array}$ \\
\hline Nephritis rat & $\begin{array}{l}\text { Rabbit anti-glomerular } \\
\text { BM serum }\end{array}$ & $\begin{array}{l}\text { Gal-1 }(1 \mathrm{mg} / \mathrm{kg}) \text { i.p. on } \\
\text { alternate days for } \\
2 \text { weeks }\end{array}$ & $\begin{array}{l}\text { Reduced crescent formation, } \\
\text { proliferation of glomerular } \\
\text { cells and macrophage } \\
\text { infiltration }\end{array}$ & $\begin{array}{l}\text { Tsuchiyama } \\
\text { et al. (2000) }\end{array}$ \\
\hline $\begin{array}{l}\text { Autoimmune uveitis } \\
\text { mouse }\end{array}$ & $\begin{array}{l}\text { Interphotoreceptor } \\
\text { retinoid-binding } \\
\text { protein }\end{array}$ & $\begin{array}{l}50 \mu \mathrm{g} \text { Gal-1 i.p. during } \\
\text { afferent (days } 2,4,6 \text { ) or } \\
\text { efferent (days } 14,16,18) \\
\text { phases }\end{array}$ & $\begin{array}{l}\text { Prevents ocular pathology. } \\
\text { Decreases leukocyte } \\
\text { infiltration }\end{array}$ & $\begin{array}{l}\text { Toscano } \\
\text { et al. (2006) }\end{array}$ \\
\hline Pneumonia mouse & S. Pneumoniae & $\begin{array}{l}5 \mu \mathrm{g} \text { of Gal-3 intratracheally } \\
\text { at time of infection }\end{array}$ & $\begin{array}{l}\text { Decreased lung injury and } \\
\text { bacteraemia. Reduced } \\
\text { levels of IL6 and TNF in } \\
\text { BAL fluid. }\end{array}$ & $\begin{array}{l}\text { Farnworth } \\
\text { et al. (2008) }\end{array}$ \\
\hline Arthritis mouse & Collagen type II & $\begin{array}{l}\text { Gal-9 }(10 \mu g) \text { i.v. daily from } \\
\text { second immunisation } \\
\text { at day } 21\end{array}$ & $\begin{array}{l}\text { Increased number of apoptotic } \\
\text { cells in joint. Reduced } \\
\text { clinical score and cellular } \\
\text { infiltrate }\end{array}$ & $\begin{array}{l}\text { Seki } \\
\quad \text { et al. (2007) }\end{array}$ \\
\hline $\begin{array}{l}\text { Experimental allergic } \\
\text { encephalomyelitis } \\
\text { mouse }\end{array}$ & $\begin{array}{l}\text { Myelin oligodendrocyte } \\
\text { glycoprotein }\end{array}$ & $\begin{array}{l}\text { Stable Gal-9 }(100 \mu \mathrm{g}) \text { i.p. } \\
\text { daily from day } 3 \text { to } 7\end{array}$ & $\begin{array}{l}\text { Decreased antigen-specific } \\
\text { IFNG producing Th1 cells. } \\
\text { Reduced mortality and } \\
\text { disease severity }\end{array}$ & $\begin{array}{l}\text { Zhu } \\
\quad \text { et al. (2005) }\end{array}$ \\
\hline Asthma mouse & $\begin{array}{l}\text { Dermatophagoides } \\
\text { farinae allergen }\end{array}$ & $\begin{array}{l}\text { Stable Gal-9 }(10-100 \mu g) \\
\text { i.v. } 24 \mathrm{~h} \text { or } 1 \mathrm{~h} \text { before } \\
\text { and } 8 \mathrm{~h} \text { after intranasal } \\
\text { antigen challenge }\end{array}$ & $\begin{array}{l}\text { Inhibited Th2 cell infiltration } \\
\text { into the lung. Reduced } \\
\text { airway hyperresponsiveness }\end{array}$ & $\begin{array}{l}\text { Katoh } \\
\text { et al. (2007) }\end{array}$ \\
\hline Nephritis rat & $\begin{array}{l}\text { Rabbit anti-glomerular } \\
\text { BM serum }\end{array}$ & $\begin{array}{l}\text { Gal-9 }(1 \mathrm{mg} / \mathrm{kg}) \text { i.p. } \\
\text { on alternate days for } \\
2 \text { weeks }\end{array}$ & $\begin{array}{l}\text { Induced apoptosis of CD8A }{ }^{+} \mathrm{T} \\
\text { cells. Inhibited macrophage } \\
\text { infiltration and crescent } \\
\text { formation }\end{array}$ & $\begin{array}{l}\text { Tsuchiyama } \\
\text { et al. (2000) }\end{array}$ \\
\hline Skin transplant mouse & Allogeneic skin grafts & $\begin{array}{l}\text { Gal-9 }(100 \mu \mathrm{g}) \text { daily } \\
\text { post-transplant }\end{array}$ & $\begin{array}{l}\text { Induced apoptosis of } \mathrm{CD} 8 \mathrm{~A}^{+} \mathrm{T} \\
\text { cells. Prolonged skin graft } \\
\text { survival }\end{array}$ & $\begin{array}{l}\text { Wang } \\
\quad \text { et al. (2007) }\end{array}$ \\
\hline
\end{tabular}

therapeutic applications (Thijssen et al. 2007). This report supports the notion that endothelial Gal-1 should be suppressed in tumours, whereas hr-Gal-1 or Gal-1 mimetics should be targeted to the endothelium during chronic inflammation to prevent over-reactive immune responses. Recent studies have shown that Gal-1 null mice display an attenuated response in a model of chronic hypoxia-induced pulmonary hypertension, highlighting a likely role for Gal-1 in vascular remodelling (Case et al. 2007).

An intriguing critical role for Gal-1 has recently been demonstrated in fetomaternal tolerance, with Gal-1 null mice displaying increased foetal loss. Gal-1 was shown to induce the development of tolerogenic dendritic cells early on in successful pregnancies therefore promoting expansion of IL10-producing regulatory $\mathrm{T}$ cells (Blois et al. 2007). Relevantly, elevated placental Gal-1 levels have been demonstrated in patients with severe pre-eclampsia, implicating a role for Gal-1 in fetomaternal tolerance in humans (Than et al. 2008).

Following antigen-induced activation of murine $\mathrm{T}$ cells, Gal-1 synthesis is upregulated and consequently inhibits antigen-induced proliferation of naive and memory 
$\mathrm{CD} \mathrm{A}^{+} \mathrm{T}$ cells, thus acting as an autocrine negative feedback loop on T-cell reactivity (Blaser et al. 1998). Further analysis clarified that Gal-1 arrests cell cycle progression between the $\mathrm{S}$ and $\mathrm{G} 2 / \mathrm{M}$ phases, thereby switching off T-cell effector functions (Allione et al. 1998). This mechanism may be in place to ensure that the immune response mounted declines appropriately after antigen is cleared. It is therefore likely that the adaptive immune response would be overactive in Gal-1 null mice. Supporting this concept, a recent study indicates that Gal-1 modulates the Th1 and Th17 but not the Th2 life span, thus Gal-1 null mice exhibit 'hyper' Th1 and Th17 responses thereby making them more susceptible to an experimental model of multiple sclerosis (Toscano et al. 2007). Additionally, emerging data have illuminated an important suppressive function of Gal-1 in regulatory $\mathrm{T}$ cells, thus acting as a negative regulator of the adaptive immune response (Garin et al. 2007). The phenotype of the Gal-1 null mice is outlined in Table 1.

\section{Actions of exogenous galectin-3}

Gal-3 (LGALS3 antigen, IGE-binding protein, carbohydrate binding protein-35, epsilon BP, HL-29, RL-29) was first identified as an antigen expressed on the surface of murine thioglycollate-elicited macrophages (Ho \& Springer 1982). In contrast to Gal-1, Gal-3 has been largely purported to have a pro-inflammatory role with its increased expression in a host of inflammatory/immune disorders underscoring its potential roles in inflammation.

Increased levels of Gal-3 have been detected in: bronchoalveolar lavage (BAL) fluid in OVA-challenged mice with macrophages being major cell type containing Gal-3 (Zuberi et al. 2004), in prion-infected brain tissue (Mok et al. 2007), in thymus following Trypanosoma cruzi infection (Silva-Monteiro et al. 2007) as well as synovial tissue from RA patients (Ohshima et al. 2003). Levels as high as $50 \mu \mathrm{g} / \mathrm{ml}$ have been detected in the BAL fluid of mice after infection with Streptococcus pneumoniae (Farnworth et al. 2008). In addition, Gal-3 expression has been linked to increased malignancy in a number of tumours (Inohara et al. 2008, Saussez et al. 2008) and may be of use as a marker for determining stages of certain tumours (Balasubramanian et al. 2008, Matsuda et al. 2008). The role of Gal-3 in innate immunity is supported by studies showing that neutrophil and macrophage recruitment is attenuated in in vivo models of peritonitis conducted in mice nullified for this lectin (Colnot et al. 1998b, Hsu et al. 2000). This is further corroborated by in vitro studies in which recombinant Gal-3 promotes neutrophil-endothelial interactions (Sato et al. 2002).

During inflammation Gal-3 is released into the extracellular space where it may activate inflammatory cells or contribute to their retention by increasing cellular interactions with extracellular matrix glycoproteins. In line with a proinflammatory role, exogenous Gal-3 has been demonstrated to activate numerous cell types involved in the inflammatory/ immune response; namely, inducing mast cell degranulation
(Frigeri et al. 1993, Suzuki et al. 2008), IL1 and superoxide production in monocytes (Jeng et al. 1994, Liu et al. 1995) and superoxide and IL8 generation and L-selectin shedding in neutrophils (Yamaoka et al. 1995, Nieminen et al. 2005, Farnworth et al. 2008). Indication for a positive loop at the level of the neutrophil has emerged: Gal-3 increases cellular expression of CEACAM1 and CEACAM8, which then act as receptors for transducing Gal-3-mediated activation of NAD $(\mathrm{P}) \mathrm{H}$ oxidase activity (Feuk-Lagerstedt et al. 1999, Fernandez et al. 2005). Interestingly, primed neutrophils are then capable of deactivating Gal-3 by causing its cleavage mainly via the serine protease elastase (Nieminen et al. 2005).

As well as promoting cellular activation, exogenous Gal-3 also promotes cellular adhesion. Administration of hr-Gal-3 promotes adhesion of neutrophils to laminin in a carbohydrate-dependent, calcium-independent manner, while in the presence of divalent cations Gal-3 activates neutrophils increasing their adhesion to other ligands such as fibronectin (Kuwabara \& Liu 1996). Gal-3 also promotes neutrophil adhesion to endothelial cells in vitro and may play an important role in beta-2 integrin-independent neutrophil extravasation in vivo (Sato et al. 2002). These results, along with a decreased cellular infiltrate observed in numerous in vivo models of inflammation performed in Gal-3 null mice, provide evidence for a role for this galectin in mediating leukocyte recruitment during an inflammatory response (Colnot et al. 1998a,b, Bernardes et al. 2006, Nieminen et al. 2008)

With regards to apoptosis, Gal-3 appears to function differently in relation to its localisation, i.e. whether it is inside or outside the cell. Intracellular Gal-3 would inhibit apoptosis, which may then lead to persistence of blood-borne cells at the sites of inflammation. Inhibition of apoptosis is thought to be due to Gal-3 localising to the mitochondria, preventing cytochrome c release (Moon et al. 2001, Yu et al. 2002). This protective effect of intracellular Gal-3 appears to function in numerous cell types and in response to a wide range of apoptosis-inducing agents. Overexpression of Gal-3 in human leukaemic $\mathrm{T}$ cells conferred resistance to apoptosis induced by anti-FASN antibody and staurosporine (Yang et al. 1996), while overexpression in breast carcinoma cells increased resistance against cisplatin and free radical-induced apoptosis (Akahani et al. 1997, Moon et al. 2001). Accordingly, cells that lack intracellular Gal-3 are more susceptible to apoptosis as shown by increased apoptosis of peritoneal macrophages from Gal-3 null mice and increased UVB-induced apoptosis of Gal-3 null keratinocytes (Saegusa et al. 2008), an effect thought to be consequent to suppression of Erk phosphorylation and enhancement of $A k t$ activation.

Like Gal-1, exogenous Gal-3 induces phosphatidylserine exposure and apoptosis of $\mathrm{T}$ cells (Fukumori et al. 2003, Stillman et al. 2006, Stowell et al. 2008). Gal-1 and Gal-3 both bind numerous receptors on $\mathrm{T}$ cells with some overlap, although while CD7 has been linked to Gal-1-induced apoptosis (Pace et al. 2000), Gal-3 does not bind this receptor. It does however, interact with ITGB1, SPN, PTPRC and TFRC, all of which have been linked - in various ways - to 
apoptosis. Stillman et al. (2006) found, however, that ITGB1 and SPN were not required for Gal-3-induced apoptosis, while cells lacking PTPRC did not respond to Gal-3 application with apoptosis. TFRC also appears to play a role with clustering of this receptor observed in all apoptotic cells. Following infection with T. cruzi recombinant, Gal-3 induced increased levels of death in cortical immature thymocytes while thymuses from Gal-3 null mice did not show cortical depletion after parasite infection in vivo (Silva-Monteiro et al. 2007). Treatment with hr-Gal-3 ( $\geq 100 \mathrm{nM}$ for 18-44 h) can induce apoptosis of mast cells in a carbohydrate, RAGE and caspase-3 dependent manner (Suzuki et al. 2008). The effect of Gal-3 on neutrophil apoptosis is not fully defined with one report showing that hr-Gal-3 enhances the apoptotic rate of this cell type (Fernandez et al. 2005), and more recent studies have reported that Gal-3, similar to Gal-1, induces phosphatidylserine exposure on neutrophils without inducing apoptosis (Stowell et al. 2008): in fact Farnworth et al. (2008) found that Gal-3 could delay neutrophil apoptosis. It is plausible that these differences may be due to the concentration and treatment duration of Gal-3 used in these assays, with low concentrations for a short pre-incubation period $(0.4 \mu \mathrm{g} / \mathrm{ml}, 15 \mathrm{~min})$ enhancing apoptosis (Fernandez et al. 2005) and higher concentrations for more prolonged incubation periods $(30 \mu \mathrm{g} / \mathrm{ml}, 18 \mathrm{~h}$ ) delaying it (Farnworth et al. 2008).

In line with its effects on cellular activation and adhesion, Gal-3 also promotes chemotaxis of monocytes in vivo and macrophages in vitro $(1 \mu \mathrm{M})$ (Sano et al. 2000) as well as eosinophils in OVA-induced asthma (Zuberi et al. 2004). One facet of inflammation where Gal-3 appears to have beneficial effects is phagocytosis. Phagocytosis is necessary to clear pathogens, foreign bodies and cellular debris, thus allowing inflammation to resolve. Gal-3 has been found to play a critical role in macrophage phagocytosis with Gal-3 null macrophages demonstrating decreased phagocytosis of IgG-opsonised erythrocytes and thymocytes in vitro; moreover, Gal-3 null mice display reduced phagocytosis of red blood cells by kupffer cells in a model of haemolytic anaemia (Sano et al. 2003). Treatment with hr-Gal-3 increases phagocytosis of apoptotic neutrophils by monocyte-derived macrophages (Karlsson et al. 2008), and this is in agreement with the fact that Gal-3 null macrophages demonstrate reduced phagocytosis of apoptotic neutrophils (Farnworth et al. 2008). As well as increasing macrophage phagocytosis, Gal-3 also enhances the phagocytic capabilities of neutrophils, a fact that may in part account for the protective role of Gal-3 in infections such as S. pneumoniae (Farnworth et al. 2008).

The anti-inflammatory nature of Gal-1 is thought to be due, at least in part, to its ability to skew the Th1/Th2 balance in favour of a Th2-type response. By contrast, Gal-3 suppresses type-2-mediated inflammation by inhibiting IL5 production by eosinophils and antigen-specific T-cell lines, suggesting a potential role in allergic inflammation (Cortegano et al. 1998). In line with this, gene therapy experiments have shown that treatment of asthmatic rats with a plasmid encoding Gal-3 improves the eosinophil count in these animals and normalises airway hyper-responsiveness to methacholine (Lopez et al. 2006). However, a previous study in Gal-3 null mice suggested a pro-inflammatory role for Gal-3 with increased levels of IFNG and decreased levels of IL4 in OVA-challenged mice, which is indicative of a higher Th1 response; these mice also had lower eosinophilic infiltration and airway hyper-responsiveness (Zuberi et al. 2004). The differences between these two studies may result from differing effects of the endogenous protein when compared with Gal-3 overexpression or compensatory mechanisms in the Gal-3 null mice by other members of the galectin family. Gal-3 has also been shown to modulate T-cell behaviour; inhibition of Gal-3 using antisense technology blocks proliferation of TCR-stimulated T cells (Joo et al. 2001). The strongest evidence has arisen from mice deficient in mannosyl (alpha-1,6-)-glycoprotein beta1,6-N-acetyl-glucosaminyltransferase (Mgat5); these mice show increased TCR activation, susceptibility to autoimmune disease and an enhanced Th1 response, all attributable to inefficient formation of multivalent lattices of Gal-3 and $\mathrm{N}$-glycans in the TCR complex (Demetriou et al. 2001).

One area of Gal-3 biology that could potentially be exploited positively is during the resolution of inflammation. Alternative activation of macrophages drives resolution and occurs when macrophages are stimulated with the Th2 cytokines IL4 or IL13. Such activation has been implicated in a number of pathologies including host response to parasitic infections, asthma, wound repair and fibrosis in granulomatous disease. Gal-3 appears to be required for alternative activation of macrophages as siRNA depletion of Gal-3 blocks IL4-mediated alternative activation as measured by arginase activation and alternative marker expression; classical activation induced by IFNG/LPS was not affected (MacKinnon et al. 2008). Furthermore, alternative activation with IL4 and IL13 stimulates Gal-3 expression and release while classical activation with IFNG/LPS inhibits Gal-3 expression. Studies describing the actions of administration of recombinant Gal-3 in vivo are outlined in Table 2.

\section{Galectin-3 and the in vivo immune response}

Gal-3 null mice, like their Gal-1 null counterparts, develop normally and are viable and fertile (Colnot et al. 1998a), indeed Gal-1/Gal-3 double knockouts are also viable (Colnot et al. 1998a). It has recently been found, however, that Gal-3 null mice spontaneously develop pathological changes in the liver at 6 months of age typical of non-alcoholic fatty liver disease. These changes may be due to the function of Gal-3 as a receptor for advanced glycation end products (AGEs), with levels of AGE and the AGE receptor RAGE increased in Gal-3 null mice (Nomoto et al. 2006). Numerous studies have, however, now been carried out using these mice and comparisons between wild-type and Gal-3 null mice have supported the concept that this lectin plays a predominantly pro-inflammatory role in vivo. 
Several studies have shown that Gal-3 null mice exhibit a reduced inflammatory response compared with wild-type mice, thus emphasising the pro-inflammatory nature of this protein. Lower numbers of neutrophils are recruited to the peritoneum following injection of thioglycollate (Colnot et al. 1998b) and to the lungs following S. pneumoniae infection (Nieminen et al. 2008). Neutrophil recruitment in S. pneumoniae is independent of $\beta 2$ integrin whereas the $\beta 2$ integrin-dependent recruitment in Escherichia Coli infection was not affected by the lack of Gal-3 (Nieminen et al. 2008). Increased survival of Gal-3 null mice has been observed following intracerebral and peripheral scrapie infection (Mok et al. 2007), while Gal-3 null mice have reduced granuloma formation following infection with Schistosomiasis (Breuilh et al. 2007), a disease normally characterised by a Th2-driven response. Gal-3 null mice, however, mounted a biased Th1 response as demonstrated by increased IFNG and IgG2b levels. Gal-3 appears to alter strength of immune response triggered by DCs. Mature DCs from null mice induced increased proliferation as well as enhanced production of IFNG and Il4 by T cells. Infection of Gal-3 null mice with another parasite, T. Gondii again resulted in decreased inflammation and a higher Th1 response evident by increased levels of IFNG and IL12 (Bernardes et al. 2006). Decreased survival of null mice when the parasite was given an i.p. injection was associated with a deficient influx of PMN and macrophages into the peritoneal cavity.

Although Gal-3 appears to play a deleterious role in a host of inflammatory and immune conditions, the opposite appears to be the case in conditions such as diabetes where advanced glycation end products (AGEs) play a role in disease pathogenesis (Pugliese et al. 2001, Iacobini et al.2004). AGEs are formed as a result of hyperglycaemia and are known to be pathogenic mediators of most complications that result from diabetes (Peppa et al. 2003). Gal-3 has been identified as an AGE receptor (AGE-R3) (Vlassara et al. 1995) that binds AGEs with high affinity leading to their internalisation and degradation. Thus, the Gal-3-AGE R pathway is believed to act as a protective mechanism toward AGE-induced injury (Pugliese et al. 2001). In support of this, Gal-3 null mice develop accelerated glomerulopathy in a model of streptozotocin-induced diabetes with pronounced increases in circulating and renal/glomerular AGE levels (Pugliese et al. 2001). Gal-3 may also influence expression of other AGE-binding proteins, this being supported by the observation that nondiabetic Gal-3 null mice have reduced renal/glomerular levels of AGE-R1 (DDOST) and MSR1 (implicated in AGE removal) and increased AGE-R2 (PRKCSH) and RAGE (AGER) (mediate cell activation). As a result, the cell's ability to remove AGEs may be compromised. Not all of the effects of Gal-3 in diabetes occur as a result of its function as an AGER. Canning et al. (2007) showed significantly less diabetesmediated inner blood-retinal barrier dysfunction in Gal-3 null mice than wild-type counterparts at 2 weeks, a time point at which AGE levels are comparable with non-diabetic controls, it was therefore suggested that Gal-3 may alter vascular cell function independently of AGE binding due to its numerous pro-inflammatory actions. Suppression of angiogenesis during diabetes is a recognised phenomenon. Retinal ischaemia and neovascularisation were studied in a murine model of oxygen-induced proliferative retinopathy in wild-type and Gal-3 null mice after perfusion of preformed AGEs. Ablation of Gal-3 abolished the AGE-mediated increase in ischaemia and restored the neovascular response to that seen in controls (Stitt et al. 2005). Independent of AGE binding, Gal-3 has been shown to increase angiogenesis (Nangia-Makker et al. 2000); therefore, it may only be antiangiogenic in a diabetic environment.

In contrast to its pro-inflammatory nature, Gal-3 null mice are more susceptible to endotoxic shock than wild-type mice with increased production of pro-inflammatory cytokines and NO (Li et al. 2008). Gal-3 has been found to bind LPS of numerous bacteria including Klebsiella pneumoniae, Salmonella typhimurium and E. Coli (Mey et al. 1996). These interactions are thought to occur via both the CRD and N-terminal domain of Gal-3. Gal-3 null macrophages had elevated LPSinduced signalling and cytokine generation compared with wild-type cells that was inhibited by recombinant Gal-3, while blocking Gal-3 with a neutralising Ab in wild-type cells increased their production of cytokines in response to LPS. By contrast, Gal-3 was found to favour salmonella survival (Li et al. 2008). Gal-3 null mice developed an increased Th1 response in response to salmonella infection, which might have contributed to its reduced replication in the Gal-3 null mice. The phenotype of the Gal-3 knockout mice is outlined in Table 1.

As well as binding LPS, Gal-3 also interacts with Candida albicans through $\beta-1,2$ mannosides. Gal-3 was found to localise at the level of phagocytic cups formed around yeasts and at the periphery of ingested yeasts (Jouault et al. 2006). The data suggest that macrophages differentially sense $C$. albicans and $S$. cerevisiae through a mechanism involving TLR2 and Gal-3, which were shown to be associated in differentiated macrophages following incubation with $C$. albicans.

\section{Actions of exogenous galectin-9}

Gal-9 (LGALS9) was originally identified as a potent eosinophil chemoattractant produced and released by antigen-stimulated T cells (Matsumoto et al. 1998). Furthermore, this lectin was also shown to act directly on eosinophils, inducing aggregation, superoxide production and prolonging their survival (Matsumoto et al. 2002). Yet, the role of Gal-9 in allergic inflammation has yet to be fully characterised. There are some discrepancies regarding the relationship between Gal-9 and asthma, since this galectin seemed not to be involved in the pathology of airway hypersensitivity using a guinea pig model (Yamamoto et al. 2007), while, in murine, mite allergen-induced asthma Gal-9 was shown to reduce airway hyper-responsiveness and lung inflammation, an effect thought to be therapeutically linked to its ability to modulate T-cell infiltration into the airway (Katoh et al. 2007). 
Gal-9 has been shown to be a potent activator of dendritic cell maturation and hence an initiator of the adaptive immune response. Comparative to LPS, Gal-9 caused an upregulation of maturation markers and co-stimulatory molecules on DC, and induced IL12 secretion in a dosedependent manner, eliciting the secretion of Th1 cytokines by allogeneic $\mathrm{CD} 4{ }^{+} \mathrm{T}$ cells (Dai et al. 2005). Similarly to Gal-1, Gal-9 is also known to induce apoptosis of thymocytes (Wada et al. 1997) and peripheral T cells (Kashio et al. 2003), implicating a role in both T-cell maturation and in the modulation of T-cell-mediated immune reactions. However, these two galectins require different ligands and utilise distinct intracellular cell death pathways to induce apoptosis, due to their distinct structural features (Bi et al. 2008).

Gal-9-mediated apoptosis has been demonstrated in a nephrotoxic serum nephritis animal model (Tsuchiyama et al. 2000) and a model of diabetic nephropathy (Baba et al. 2005), producing efficacious outcomes in both models. Daily administration of Gal-9 improved survival of allogeneic skin grafts in mice, which was proposed to be due to apoptosis of host cytotoxic CD8A ${ }^{+} \mathrm{T}$ cells (Wang et al. 2007). A beneficial effect of Gal-9-induced apoptosis was also demonstrated in a model of collagen-induced arthritis, suppressing pannus formation, bone erosion and inflammatory infiltrate (Seki et al. 2007). Indeed, apoptotic cells were identified within RA synovial tissue implanted into SCID mice following Gal-9 treatment. Gal-9 was shown to preferentially induce apoptosis of fibroblast-like synoviocytes isolated from RA compared with OA patients, indicating a potential mechanism for the suppression of RA (Seki et al. 2007).

A novel binding partner for Gal-9 was identified in 2005 by Zhu and colleagues; T-cell immunoglobulin and mucindomain-containing protein-3 (HAVCR2; previously known as TIM3), shown to be expressed on terminally differentiated Th1 cells (Zhu et al. 2005). In a HAVCR2-dependent manner, Gal-9 triggered calcium entry, aggregation and apoptosis of Th1 cells. Pathological relevance was demonstrated with exogenous administration of Gal-9, which decreased disease severity and mortality in an experimental allergic encephalitis model (Zhu et al. 2005). Importantly, Gal-9 is involved in a negative feedback loop, whereby IFNG that is known to induce Gal-9 (Asakura et al. 2002, Imaizumi et al. 2002) consequently suppresses Th1 cells, thus preventing prolonged inflammation and allowing efficient resolution. An exciting recent report has revealed that Gal-9 specifically induces the formation of regulatory $\mathrm{T}$ cells, while simultaneously repressing the generation of pro-inflammatory Th17 cells in a model of collagen-induced arthritis (Seki et al. 2008). Treatment with Gal-9 significantly decreased the formation of pro-inflammatory IL17, IL12 and IFNG within the joint, and lowered the percentage of peripheral blood $\mathrm{CD} 4{ }^{+} \mathrm{HAVCR}^{+} \mathrm{T}$ cells. Studies describing the actions of administration of recombinant Gal-9 in vivo are outlined in Table 2.

\section{Galectin-9 and the in vivo immune response}

Only a limited number of studies have been performed utilising the Gal-9 null mouse to date. Strikingly, Gal-9deficient mice have an enhanced incidence of developing collagen-induced arthritis; most notably, this phenotype is evident in a C57BL/6J strain, which is normally resistant to CIA. These null mice have increased numbers of HAVCR $2{ }^{+} \mathrm{CD} 4^{+} \mathrm{T}$ cells compared with wild-type mice, substantiating the role of Gal-9 in the modulation of Havcr2positive cells in vivo (Seki et al. 2008). Functionality of Gal-9 during infection has recently been highlighted in LPSinduced inflammation. Mice treated with Gal-9 had greatly improved survival rates, whereas Gal-9 null mice were prone to increased mortality and died within $72 \mathrm{~h}$ of LPS induction. The proposed target cell for Gal-9-mediated suppression in this model is PMN, because neutropenic mice were no longer protected from the beneficial effects of Gal-9 (Tsuboi et al. 2007). The phenotype of the Gal-9 null mice is outlined in Table 1.

\section{Targets (receptors) for Gal-1, Gal-3 and Gal-9}

The extracellular matrix (ECM) consists of numerous components including collagen, glycosaminoglycans, laminin, fibronectin and many other glycoproteins. Its classical function is to provide structural support for tissues, but it is also shown to play a more active role in regulating the behaviour of cells that contact it (Streuli 1999). Two main ways in which this is achieved is by direct cell-ECM interactions and by its association with growth factors (Taipale \& Keski-Oja 1997). Several ECM components have been identified as ligands for Gal-1 and Gal-3, including laminin and fibronectin (Zhou \& Cummings 1993, Ozeki et al. 1995, Kuwabara \& Liu 1996). Association of Gal-1 with ECM proteins causes a direct reduction in leukocyte adhesion, as well as inhibiting T-cell migration through the ECM (He \& Baum 2006), whereas Gal-3 localisation with ECM enhances leukocyte adhesion. Gal-9 has also been shown to reduce tumour cell adhesion by preventing binding to ligands on the endothelium and ECM (Nobumoto et al. 2008).

Other acceptors/ligands for galectins include membrane proteins such as integrins, lysosome-associated membrane proteins (LAMPs) and even certain gangliosides. The Gal-1 ligand ganglioside GM1 has recently been identified as important for endocytosis of Gal-1 in Jurkat cells, a process mediated by clathrin and lipid raft-dependent mechanisms, although the reason for internalisation remains to be established (Fajka-Boja et al. 2008). Gal-1 binds to a number of leukocyte cell surface molecules including CD4, CD7, SPN and PTPRC (Perillo et al. 1995, Hernandez \& Baum 2002, Stillman et al. 2006). However, the precise carbohydrate structures on these macromolecules, which are recognised by galectins, are not well defined. Studies utilising biotinylated 
galectins have illustrated binding partners for Gal-1 and Gal-3 on the lymphocyte. Pre-incubation of lymphocytes with Gal-3 results in a partial displacement in binding of Gal-1 (Stillman et al. 2006), suggesting some binding sites are Gal-1 specific, or alternatively that Gal-1 has a higher affinity for these sites than Gal-3. Indeed, it is well known that the galectins display differing oligosaccharide-binding specificity due to the subtle differences in their CRDs (Hirabayashi et al. 2002).

The study of He \& Baum (2006) illustrated that Gal-1 clusters SPN on the T-cell surface, which is thought to retard SPN redistribution to the trailing edge during transmigration and hence inhibit this process. During lymphocyteendothelial interactions, lymphocytes become polarised due to chemokine activation and form a cellular projection at the rear referred to as a uropod where certain proteins are relocated including SPN, CD44 and PTPRC (del Pozo et al. 1997). It is therefore intriguing to hypothesise that due to Gal-1 preventing the relocalisation of these bulky glycoproteins to the uropod, this could result in steric hindrance to molecules such as LFA1 from interacting with endothelial adhesion molecules (Manjunath et al. 1995).

It is also possible, however, that Gal-1 could signal through one/or both of these receptors to decrease lymphocyte recruitment. Of particular interest, a parallel was found between upregulated PTPRC expression on lymphocytes that have rolled over the activated endothelium and the degree of binding of biotGal-1, suggesting that the two events are closely interlinked (our unpublished observations). This raises important questions about the downstream signalling events transmitted by Gal-1 binding. PTPRC is the prototype tyrosine phosphatase expressed on $\mathrm{T}$ cells, and regulates the activity of $\mathrm{p} 56^{\mathrm{Lck}}$ (LCK) kinase by dephosphorylating the negative regulatory tyrosine residue (Y505). PTPRC activity itself can be regulated through autoinhibition by dimerisation (Mustelin et al. 2005). Reports indicating that binding of Gal-1 to PTPRC causes clustering and a decrease in its intrinsic protein tyrosine phosphatase (PTP) activity (Walzel et al. 1999, Fouillit et al. 2000, Amano et al. 2003) suggest that Gal-1 would function to decrease LCK activity. Indeed, pre-treatment of lymphocytes with an LCK kinase inhibitor mimicked the effects of exogenous hr-Gal-1 in inhibiting lymphocyte recruitment within the flow chamber. Combining the two treatments of hr-Gal-1 and the LCK kinase inhibitor were not additive, suggesting sharing of the same or similar pathway(s). These inhibitor studies suggest that Gal-1 acts on PTPRC to possibly cause inhibition of the Src kinase $\mathrm{p} 56^{\text {Lck }}$, thereby bringing about its inhibitory effect on lymphocyte adhesion. It is also possible to hypothesise that Gal-1 would bind to another receptor, and then activate a signalling cascade that would impact on PTPRC activity. Notably, the Src kinase $\mathrm{p} 56^{\text {Lck }}$ is a key determinant for a high-affinity state of VLA4 on circulating lymphocytes, allowing rapid response to chemokines on the endothelium (Feigelson et al. 2001).
An opposing mechanism has been proposed for Gal-3, which is thought to cause redistribution of the large MUC1 antigen on cancer cells, thus allowing topological accessibility of ligands on these cancer cells to interact with endothelial counter receptors, enhancing adhesion (Yu et al. 2007). Further evidence for this mechanism was demonstrated by pre-treatment of HUVEC with anti-E-selectin or anti-CD44H antibodies, which caused a reduction in Gal-3-mediated cell adhesion (Yu et al. 2007).

Of interest, studies by Katoh and colleagues have demonstrated efficacy of Gal-9 in a model of mite allergeninduced asthma, an effect therapeutically linked to its ability to modulate CD44-mediated functions. Gal-9, but not other members of the galectin family, has been shown to directly inhibit CD44 from binding to its ligand hyaluronan, in a carbohydrate-dependent fashion (Katoh et al. 2007). CD44 is normally expressed in an inactive form on naive lymphocytes, which lacks ligand-binding activity, and can be converted to an active form upon lymphocyte activation (English et al. 1998). This receptor on activated lymphocytes mediates rolling on hyaluronate, and functions as an additional mechanism to the canonical selectin-mediated rolling during inflammation. (DeGrendele et al.1996, 1997).

Galectin research to date has largely focused on the role of these proteins in animal models of disease such as collageninduced arthritis, EAE, diabetes and infection by various parasitic organisms. To date, clinical data are restricted to the expression of these proteins in human tissue biopsy samples with increased expression of Gal-3 and Gal-9 detected in synovium taken from rheumatoid arthritis patients compared with the less inflamed osteoarthritic synovium (Ohshima et al. 2003, Seki et al. 2007), while Gal-1 expression is downregulated in synovium from patients with juvenile idiopathic arthritis (Harjacek et al. 2001). Expressions of Gal-1 and Gal-9 have also been observed in numerous tumours and may be linked to malignancy. Due to the immune modulatory properties of Gal-1, Gal-3 and Gal-9, it is likely that all three have some role in malignancy (for an extensive review on galectins in tumour progression, see Liu \& Rabinovich 2005).

\section{From patho-physiology to pharmacology, oppor- tunities for new anti-inflammatory therapeutics}

As outlined in this review, overwhelming experimental evidence demonstrates that galectins play key roles in immune, infectious and inflammatory reactions, by providing stimulatory or inhibitory signals. The temporal and spatial expression of Gal-1, -3 and -9 during inflammatory episodes is likely to be in place to co-ordinate and finely regulate the host response. The individual galectins discussed here have distinct biological actions due to their unique structural features, and hence their binding preferences for different ligands. The same galectin may also display differing effects depending on cellular compartmentalisation, concentration in the local milieu and differentiation status of the target cell. 
Indeed, the regulated expression of glycosyltransferases leads to creation (or masking) of different galectins ligands during differentiation and activation of T cells, accordingly Gal-1, -3 and -9 act on different subsets demonstrating lineage-specific recognition and bioactions. It is plausible that cell-to-cell crosstalk might lead to the identification of a galectin network in inflammation such that, for instance, Gal-9 expression might be under the control of other members of the galectin family. In any case, deciphering how specific galectins exert their biological effects should provide insights into how they can be exploited for therapeutic interventions, and potentially have major clinical implications for the treatment of immune and inflammatory conditions.

\section{Declaration of interest}

The authors declare that there is no conflict of interest that could be perceived as prejudicing the impartiality of the research reported.

\section{Funding}

Funding to the authors' laboratory for the study of galectin biology in inflammation comes from the Arthritis Research Campaign UK (Nonclinical Career Development Fellowship 18103 to D C) and the William Harvey Research Foundation (M P and D C).

\section{References}

Akahani S, Nangia-Makker P, Inohara H, Kim HR \& Raz A 1997 Galectin-3: a novel antiapoptotic molecule with a functional BH1 (NWGR) domain of Bcl-2 family. Cancer Research 57 5272-5276.

Allione A, Wells V, Forni G, Mallucci L \& Novelli F 1998 Beta-galactosidebinding protein (beta GBP) alters the cell cycle, up-regulates expression of the alpha- and beta-chains of the IFN-gamma receptor, and triggers IFNgamma-mediated apoptosis of activated human T lymphocytes. Journal of Immunology 161 2114-2119.

Almkvist J, Dahlgren C, Leffler H \& Karlsson A 2002 Activation of the neutrophil nicotinamide adenine dinucleotide phosphate oxidase by galectin-1. Journal of Immunology 168 4034-4041.

Amano M, Galvan M, He J \& Baum LG 2003 The ST6Gal I sialyltransferase selectively modifies $\mathrm{N}$-glycans on CD45 to negatively regulate galectin1-induced CD45 clustering, phosphatase modulation, and T cell death. Journal of Biological Chemistry 278 7469-7475.

Asakura H, Kashio Y, Nakamura K, Seki M, Dai S, Shirato Y, Abedin MJ, Yoshida N, Nishi N, Imaizumi Tet al. 2002 Selective eosinophil adhesion to fibroblast via IFN-gamma-induced galectin-9. Journal of Immunology 169 5912-5918

Baba M, Wada J, Eguchi J, Hashimoto I, Okada T, Yasuhara A, Shikata K, Kanwar YS \& Makino H 2005 Galectin-9 inhibits glomerular hypertrophy in $\mathrm{db} / \mathrm{db}$ diabetic mice via cell-cycle-dependent mechanisms. Journal of the American Society of Nephrology 16 3222-3234.

Balasubramanian K, Vasudevamurthy R, Venkateshaiah SU, Thomas A, Vishweshwara A \& Dharmesh SM 2008 Galectin-3 in urine of cancer patients: stage and tissue specificity. Journal of Cancer Research and Clinical Oncology 19 16-20.

Barondes SH, Cooper DN, Gitt MA \& Leffler H 1994 Structure and function of a large family of animal lectins. Journal of Biological Chemistry 269 20807-20810.

Baum LG, Pang M, Perillo NL, Wu T, Delegeane A, Uittenbogaart CH, Fukuda M \& Seilhamer JJ 1995a Human thymic epithelial cells express an endogenous lectin, galectin-1, which binds to core 2 O-glycans on thymocytes and T lymphoblastoid cells. Journal of Experimental Medicine 181 877-887.

Baum LG, Seilhamer JJ, Pang M, Levine WB, Beynon D \& Berliner JA 1995 b Synthesis of an endogeneous lectin, galectin-1, by human endothelial cells is up-regulated by endothelial cell activation. Glycoconjugate Journal $\mathbf{1 2}$ 63-68.

Bernardes ES, Silva NM, Ruas LP, Mineo JR, Loyola AM, Hsu DK, Liu FT, Chammas R \& Roque-Barreira MC 2006 Toxoplasma gondii infection reveals a novel regulatory role for galectin-3 in the interface of innate and adaptive immunity. American Journal of Pathology 168 1910-1920.

Bi S, Earl LA, Jacobs L \& Baum LG 2008 Structural features of galectin-9 and galectin-1 that determine distinct $\mathrm{T}$ cell death pathways. Journal of Biological Chemistry 283 12248-12258.

Blaser C, Kaufmann M, Muller C, Zimmermann C, Wells V, Mallucci L \& Pircher H 1998 Beta-galactoside-binding protein secreted by activated T cells inhibits antigen-induced proliferation of T cells. European Journal of Immunology 28 2311-2319.

Blois SM, Ilarregui JM, Tometten M, Garcia M, Orsal AS, Cordo-Russo R, Toscano MA, Bianco GA, Kobelt P, Handjiski B et al. 2007 A pivotal role for galectin-1 in fetomaternal tolerance. Nature Medicine 13 1450-1457.

Breuilh L, Vanhoutte F, Fontaine J, van Stijn CM, Tillie-Leblond I, Capron M, Faveeuw C, Jouault T, van Die I, Gosset P et al. 2007 Galectin-3 modulates immune and inflammatory responses during helminthic infection: impact of galectin-3 deficiency on the functions of dendritic cells. Infection and Immunity 75 5148-5157.

Canning P, Glenn JV, Hsu DK, Liu FT, Gardiner TA \& Stitt AW 2007 Inhibition of advanced glycation and absence of galectin-3 prevent bloodretinal barrier dysfunction during short-term diabetes. Experimental Diabetes Research 200751837.

Case D, Irwin D, Ivester C, Harral J, Morris K, Imamura M, Roedersheimer M, Patterson A, Carr M, Hagen M et al. 2007 Mice deficient in galectin-1 exhibit attenuated physiological responses to chronic hypoxia-induced pulmonary hypertension. American Journal of Physiology. Lung Cellular and Molecular Physiology 292 L154-L164.

Cho M \& Cummings RD 1995 Galectin-1, a beta-galactoside-binding lectin in Chinese hamster ovary cells, II. Localization and biosynthesis. Journal of Biological Chemistry 270 5207-5212.

Colnot C, Fowlis D, Ripoche MA, Bouchaert I \& Poirier F 1998a Embryonic implantation in galectin 1/galectin 3 double mutant mice. Developmental Dynamics 211 306-313.

Colnot C, Ripoche MA, Milon G, Montagutelli X, Crocker PR \& Poirier F $1998 b$ Maintenance of granulocyte numbers during acute peritonitis is defective in galectin-3-null mutant mice. Immunology 94 290-296.

Cooper DN \& Barondes SH 1999 God must love galectins; he made so many of them. Glycobiology 9 979-984.

Cooper D, Norling LV \& Perretti M 2008 Novel insights into the inhibitory effects of Galectin-1 on neutrophil recruitment under flow. Journal of Leukocyte Biology 83 1459-1466.

Correa SG, Sotomayor CE, Aoki MP, Maldonado CA \& Rabinovich GA 2003 Opposite effects of galectin- 1 on alternative metabolic pathways of L-arginine in resident, inflammatory, and activated macrophages. Glycobiology 13 119-128

Cortegano I, del Pozo V, Cardaba B, de Andres B, Gallardo S, del Amo A, Arrieta I, Jurado A, Palomino P, Liu FT et al. 1998 Galectin-3 downregulates IL-5 gene expression on different cell types. Journal of Immunology $161385-389$

Craig SS, Krishnaswamy P, Irani AM, Kepley CL, Liu FT \& Schwartz LB 1995 Immunoelectron microscopic localization of galectin-3, an IgE binding protein, in human mast cells and basophils. Anatomical Record 242 211-219.

Dai SY, Nakagawa R, Itoh A, Murakami H, Kashio Y, Abe H, Katoh S, Kontani K, Kihara M, Zhang SL et al. 2005 Galectin-9 induces maturation of human monocyte-derived dendritic cells. Journal of Immunology $\mathbf{1 7 5}$ 2974-2981. 
DeGrendele HC, Estess P, Picker LJ \& Siegelman MH 1996 CD44 and its ligand hyaluronate mediate rolling under physiologic flow: a novel lymphocyte-endothelial cell primary adhesion pathway. Journal of Experimental Medicine 183 1119-1130.

DeGrendele HC, Estess P \& Siegelman MH 1997 Requirement for CD44 in activated T cell extravasation into an inflammatory site. Science $\mathbf{2 7 8}$ 672-675.

Demetriou M, Granovsky M, Quaggin S \& Dennis JW 2001 Negative regulation of T-cell activation and autoimmunity by Mgat5 $\mathrm{N}$-glycosylation. Nature 409 733-739.

Dias-Baruffi M, Zhu H, Cho M, Karmakar S, McEver RP \& Cummings RD 2003 Dimeric galectin-1 induces surface exposure of phosphatidylserine and phagocytic recognition of leukocytes without inducing apoptosis. Journal of Biological Chemistry 278 41282-41293.

Elola MT, Chiesa ME, Alberti AF, Mordoh J \& Fink NE 2005 Galectin-1 receptors in different cell types. Journal of Biomedical Science 12 13-29.

Elola MT, Wolfenstein-Todel C, Troncoso MF, Vasta GR \& Rabinovich GA 2007 Galectins: matricellular glycan-binding proteins linking cell adhesion, migration, and survival. Cellular and Molecular Life Sciences 64 1679-1700.

English NM, Lesley JF \& Hyman R 1998 Site-specific de-N-glycosylation of CD44 can activate hyaluronan binding, and CD44 activation states show distinct threshold densities for hyaluronan binding. Cancer Research $\mathbf{5 8}$ 3736-3742.

Fajka-Boja R, Blasko A, Kovacs-Solyom F, Szebeni GJ, Toth GK \& Monostori E 2008 Co-localization of galectin-1 with GM1 ganglioside in the course of its clathrin- and raft-dependent endocytosis. Cellular and Molecular Life Sciences 65 2586-2593.

Farnworth SL, Henderson NC, Mackinnon AC, Atkinson KM, Wilkinson T, Dhaliwal K, Hayashi K, Simpson AJ, Rossi AG, Haslett C et al. 2008 Galectin-3 reduces the severity of pneumococcal pneumonia by augmenting neutrophil function. American Journal of Pathology 172 395-405.

Feigelson SW, Grabovsky V, Winter E, Chen LL, Pepinsky RB, Yednock T, Yablonski D, Lobb R \& Alon R 2001 The Src kinase p56(lck) up-regulates VLA-4 integrin affinity, Implications for rapid spontaneous and chemokine-triggered $\mathrm{T}$ cell adhesion to VCAM-1 and fibronectin. Journal of Biological Chemistry 276 13891-13901.

Fernandez GC, Ilarregui JM, Rubel CJ, Toscano MA, Gomez SA, Beigier Bompadre M, Isturiz MA, Rabinovich GA \& Palermo MS 2005 Galectin-3 and soluble fibrinogen act in concert to modulate neutrophil activation and survival: involvement of alternative MAPK pathways. Glycobiology 15 519-527.

Feuk-Lagerstedt E, Jordan ET, Leffler H, Dahlgren C \& Karlsson A 1999 Identification of CD66a and CD66b as the major galectin-3 receptor candidates in human neutrophils. Journal of Immunology 163 5592-5598.

Flotte TJ, Springer TA \& Thorbecke GJ 1983 Dendritic cell and macrophage staining by monoclonal antibodies in tissue sections and epidermal sheets. American Journal of Pathology 111 112-124.

Fouillit M, Joubert-Caron R, Poirier F, Bourin P, Monostori E, Levi-Strauss M, Raphael M, Bladier D \& Caron M 2000 Regulation of CD45-induced signaling by galectin-1 in Burkitt lymphoma B cells. Glycobiology 10 413-419.

Frigeri LG, Zuberi RI \& Liu FT 1993 Epsilon BP, a beta-galactoside-binding animal lectin, recognizes $\mathrm{IgE}$ receptor ( $\mathrm{Fc}$ epsilon $\mathrm{RI}$ ) and activates mast cells. Biochemistry 32 7644-7649.

Fuertes MB, Molinero LL, Toscano MA, Ilarregui JM, Rubinstein N, Fainboim L, Zwirner NW \& Rabinovich GA 2004 Regulated expression of galectin-1 during T-cell activation involves Lck and Fyn kinases and signaling through MEK1/ERK, p38 MAP kinase and p70S6 kinase. Molecular and Cellular Biochemistry 267 177-185.

Fukumori T, Takenaka Y, Yoshii T, Kim HR, Hogan V, Inohara H, Kagawa S \& Raz A 2003 CD29 and CD7 mediate galectin-3-induced type II T-cell apoptosis. Cancer Research 63 8302-8311.

Garin MI, Chu CC, Golshayan D, Cernuda-Morollon E, Wait R \& Lechler RI 2007 Galectin-1: a key effector of regulation mediated by CD4+ CD25 + T cells. Blood 109 2058-2065.

Gil CD, Cooper D, Rosignoli G, Perretti M \& Oliani SM 2006 a Inflammation-induced modulation of cellular galectin-1 and -3 expression in a model of rat peritonitis. Inflammation Research 55 99-107.
Gil CD, La M, Perretti M \& Oliani SM $2006 b$ Interaction of human neutrophils with endothelial cells regulates the expression of endogenous proteins annexin 1, galectin-1 and galectin-3. Cell Biology International 30 338-344.

Gilroy DW, Lawrence T, Perretti M \& Rossi AG 2004 Inflammatory resolution: new opportunities for drug discovery. Nature Reviews. Drug Discovery 3 401-416.

Glinsky VV, Glinsky GV, Rittenhouse-Olson K, Huflejt ME, Glinskii OV, Deutscher SL \& Quinn TP 2001 The role of Thomsen-Friedenreich antigen in adhesion of human breast and prostate cancer cells to the endothelium. Cancer Research 61 4851-4857.

Harjacek M, Diaz-Cano S, De Miguel M, Wolfe H, Maldonado CA \& Rabinovich GA 2001 Expression of galectins-1 and -3 correlates with defective mononuclear cell apoptosis in patients with juvenile idiopathic arthritis. Journal of Rheumatology 28 1914-1922.

He J \& Baum LG 2006 Endothelial cell expression of galectin-1 induced by prostate cancer cells inhibits T-cell transendothelial migration. Laboratory Investigation 86 578-590.

Hernandez JD \& Baum LG 2002 Ah, sweet mystery of death! Galectins and control of cell fate. Glycobiology 12 127R-136R.

Hirabayashi J, Hashidate T, Arata Y, Nishi N, Nakamura T, Hirashima M, Urashima T, Oka T, Futai M, Muller WE et al. 2002 Oligosaccharide specificity of galectins: a search by frontal affinity chromatography. Biochemica and Biophysica Acta 1572 232-254.

Ho MK \& Springer TA $1982 \mathrm{Mac}-2$, a novel $32000 \mathrm{Mr}$ mouse macrophage subpopulation-specific antigen defined by monoclonal antibodies. Journal of Immunology 128 1221-1228.

Houzelstein D, Goncalves IR, Fadden AJ, Sidhu SS, Cooper DN, Drickamer K, Leffler H \& Poirier F 2004 Phylogenetic analysis of the vertebrate galectin family. Molecular Biology and Evolution 21 1177-1187.

Hsu DK, Yang RY, Pan Z, Yu L, Salomon DR, Fung-Leung WP \& Liu FT 2000 Targeted disruption of the galectin-3 gene results in attenuated peritoneal inflammatory responses. American Journal of Pathology 156 1073-1083.

Hughes RC 2001 Galectins as modulators of cell adhesion. Biochimie 83 667-676.

Iacobini C, Menini S, Oddi G, Ricci C, Amadio L, Pricci F, Olivieri A, Sorcini M, Di Mario U, Pesce C et al. 2004 Galectin-3/AGE-receptor 3 knockout mice show accelerated AGE-induced glomerular injury: evidence for a protective role of galectin-3 as an AGE receptor. FASEB Journal 18 1773-1775.

Imaizumi T, Kumagai M, Sasaki N, Kurotaki H, Mori F, Seki M, Nishi N, Fujimoto K, Tanji K, Shibata T et al. 2002 Interferon-gamma stimulates the expression of galectin-9 in cultured human endothelial cells. Journal of Leukocyte Biology 72 486-491.

Inohara H, Segawa T, Miyauchi A, Yoshii T, Nakahara S, Raz A, Maeda M, Miyoshi E, Kinoshita N, Yoshida H et al. 2008 Cytoplasmic and serum galectin-3 in diagnosis of thyroid malignancies. Biochemical and Biophysical Research Communication 376 605-610.

Jeng KC, Frigeri LG \& Liu FT 1994 An endogenous lectin, galectin-3 (epsilon BP/Mac-2), potentiates IL-1 production by human monocytes. Immunology Letters 42 113-116.

Joo HG, Goedegebuure PS, Sadanaga N, Nagoshi M, von Bernstorff W \& Eberlein TJ 2001 Expression and function of galectin-3, a beta-galactosidebinding protein in activated T lymphocytes. Journal of Leukocyte Biology 69 $555-564$.

Jouault T, El Abed-El Behi M, Martinez-Esparza M, Breuilh L, Trinel PA, Chamaillard M, Trottein F \& Poulain D 2006 Specific recognition of Candida albicans by macrophages requires galectin- 3 to discriminate Saccharomyces cerevisiae and needs association with TLR2 for signaling. Journal of Immunology 177 4679-4687.

Karlsson A, Christenson K, Matlak M, Bjorstad A, Brown KL, Telemo E, Salomonsson E, Leffler H \& Bylund J 2008 Galectin-3 functions as an opsonin and enhances macrophage clearance of apoptotic neutrophils. Glycobiology 135 355-363.

Kashio Y, Nakamura K, Abedin MJ, Seki M, Nishi N, Yoshida N, Nakamura T \& Hirashima M 2003 Galectin-9 induces apoptosis through the calcium-calpain-caspase-1 pathway. Journal of Immunology 170 3631-3636. 
Katoh S, Ishii N, Nobumoto A, Takeshita K, Dai SY, Shinonaga R, Niki T, Nishi N, Tominaga A, Yamauchi A et al. 2007 Galectin-9 inhibits CD44-hyaluronan interaction and suppresses a murine model of allergic asthma. American Journal of Respiratory and Critical Care Medicine $17627-35$.

Kuwabara I \& Liu FT 1996 Galectin-3 promotes adhesion of human neutrophils to laminin. Journal of Immunology 156 3939-3944.

La M, Cao TV, Cerchiaro G, Chilton K, Hirabayashi J, Kasai K, Oliani SM, Chernajovsky Y \& Perretti M 2003 A novel biological activity for galectin1: inhibition of leukocyte-endothelial cell interactions in experimental inflammation. American Journal of Pathology 163 1505-1515.

van der Leij J, van den Berg A, Blokzijl T, Harms G, van Goor H, Zwiers P, van Weeghel R, Poppema S \& Visser L 2004 Dimeric galectin-1 induces IL-10 production in T-lymphocytes: an important tool in the regulation of the immune response. Journal of Pathology 204 511-518.

van der Leij J, van den Berg A, Harms G, Eschbach H, Vos H, Zwiers P, van Weeghel R, Groen H, Poppema S \& Visser L 2007 Strongly enhanced IL-10 production using stable galectin-1 homodimers. Molecular Immunology 44 506-513.

Levi G, Tarrab-Hazdai R \& Teichberg VI 1983 Prevention and therapy with electrolectin of experimental autoimmune myasthenia gravis in rabbits. European Journal of Immunology 13 500-507.

Li Y, Komai-Koma M, Gilchrist DS, Hsu DK, Liu FT, Springall T \& Xu D 2008 Galectin-3 is a negative regulator of lipopolysaccharide-mediated inflammation. Journal of Immunology 181 2781-2789.

Liu FT, Hsu DK, Zuberi RI, Kuwabara I, Chi EY \& Henderson WR Jr 1995 Expression and function of galectin-3, a beta-galactoside-binding lectin, in human monocytes and macrophages. American Journal of Pathology 147 1016-1028

Liu FT, Patterson RJ \& Wang JL 2002 Intracellular functions of galectins. Biochemica and Biophysica Acta 1572 263-273.

Liu FT \& Rabinovich GA 2005 Galectins as modulators of tumour progression. Nature Review Cancer 5 29-41.

Liu SD, Whiting CC, Tomassian T, Pang M, Bissel SJ, Baum LG, Mossine VV, Poirier F, Huflejt ME \& Miceli MC 2008 Endogenous galectin-1 enforces class I-restricted TCR functional fate decisions in thymocytes. Blood $\mathbf{1 1 2}$ 120-130.

Lopez E, del Pozo V, Miguel T, Sastre B, Seoane C, Civantos E, Llanes E, Baeza ML, Palomino P, Cardaba B et al. 2006 Inhibition of chronic airway inflammation and remodeling by galectin-3 gene therapy in a murine model. Journal of Immunology 176 1943-1950.

Lotan R, Belloni PN, Tressler RJ, Lotan D, Xu XC \& Nicolson GL 1994 Expression of galectins on microvessel endothelial cells and their involvement in tumour cell adhesion. Glycoconjugate Journal 11 462-468.

MacKinnon AC, Farnworth SL, Hodkinson PS, Henderson NC, Atkinson KM, Leffler H, Nilsson UJ, Haslett C, Forbes SJ \& Sethi T 2008 Regulation of alternative macrophage activation by galectin-3. Journal of Immunology $1802650-2658$.

Manjunath N, Correa M, Ardman M \& Ardman B 1995 Negative regulation of T-cell adhesion and activation by CD43. Nature 377 535-538.

Matsuda Y, Yamagiwa Y, Fukushima K, Ueno Y \& Shimosegawa T 2008 Expression of galectin-3 involved in prognosis of patients with hepatocellular carcinoma. Hepatology Research 38 1098-1111.

Matsumoto R, Matsumoto H, Seki M, Hata M, Asano Y, Kanegasaki S, Stevens RL \& Hirashima M 1998 Human ecalectin, a variant of human galectin-9, is a novel eosinophil chemoattractant produced by T lymphocytes. Journal of Biological Chemistry 273 16976-16984.

Matsumoto R, Hirashima M, Kita H \& Gleich GJ 2002 Biological activities of ecalectin: a novel eosinophil-activating factor. Journal of Immunology 168 1961-1967.

Mey A, Leffler H, Hmama Z, Normier G \& Revillard JP 1996 The animal lectin galectin-3 interacts with bacterial lipopolysaccharides via two independent sites. Journal of Immunology 156 1572-1577.

Mok SW, Riemer C, Madela K, Hsu DK, Liu FT, Gultner S, Heise I \& Baier M 2007 Role of galectin-3 in prion infections of the CNS. Biochemical and Biophysical Research Communication 359 672-678.
Moon BK, Lee YJ, Battle P, Jessup JM, Raz A \& Kim HR 2001 Galectin-3 protects human breast carcinoma cells against nitric oxide-induced apoptosis: implication of galectin-3 function during metastasis. American Journal of Pathology 159 1055-1060.

Mustelin T, Vang T \& Bottini N 2005 Protein tyrosine phosphatases and the immune response. Nature Reviews Immunology 5 43-57.

Nangia-Makker P, Honjo Y, Sarvis R, Akahani S, Hogan V, Pienta KJ \& Raz A 2000 Galectin-3 induces endothelial cell morphogenesis and angiogenesis. American Journal of Pathology 156 899-909.

Nieminen J, St-Pierre C \& Sato S 2005 Galectin-3 interacts with naive and primed neutrophils, inducing innate immune responses. Journal of Leukocyte Biology 78 1127-1135.

Nieminen J, St-Pierre C, Bhaumik P, Poirier F \& Sato S 2008 Role of galectin-3 in leukocyte recruitment in a murine model of lung infection by Streptococcus pneumoniae. Journal of Immunology 180 2466-2473.

Nobumoto A, Nagahara K, Oomizu S, Katoh S, Nishi N, Takeshita K, Niki T, Tominaga A, Yamauchi A \& Hirashima M 2008 Galectin-9 suppresses tumor metastasis by blocking adhesion to endothelium and extracellular matrices. Glycobiology 18 735-744.

Nomoto K, Tsuneyama K, Abdel Aziz HO, Takahashi H, Murai Y, Cui ZG, Fujimoto M, Kato I, Hiraga K, Hsu DK et al. 2006 Disrupted galectin-3 causes non-alcoholic fatty liver disease in male mice. Journal of Pathology 210 469-477.

Norling LV, Sampaio AL, Cooper D \& Perretti M 2008 Inhibitory control of endothelial galectin-1 on in vitro and in vivo lymphocyte trafficking. FASEB Journal 22 682-690.

Offner H, Celnik B, Bringman TS, Casentini-Borocz D, Nedwin GE \& Vandenbark AA 1990 Recombinant human beta-galactoside binding lectin suppresses clinical and histological signs of experimental autoimmune encephalomyelitis. J Neuroimmunol 28 177-184.

Ohshima S, Kuchen S, Seemayer CA, Kyburz D, Hirt A, Klinzing S, Michel BA, Gay RE, Liu FT, Gay S et al. 2003 Galectin 3 and its binding protein in rheumatoid arthritis. Arthritis Rheum 48 2788-2795.

Ozeki Y, Matsui T, Yamamoto Y, Funahashi M, Hamako J \& Titani K 1995 Tissue fibronectin is an endogenous ligand for galectin-1. Glycobiology $\mathbf{5}$ 255-261.

Pace KE, Hahn HP, Pang M, Nguyen JT \& Baum LG 2000 CD7, delivers a pro-apoptotic signal during galectin-1-induced T cell death. Journal of Immunology 165 2331-2334.

Pacienza N, Pozner RG, Bianco GA, D'Atri LP, Croci DO, Negrotto S, Malaver E, Gomez RM, Rabinovich GA \& Schattner M 2008 The immunoregulatory glycan-binding protein galectin-1 triggers human platelet activation. FASEB Journal 22 1113-1123.

Park JW, Voss PG, Grabski S, Wang JL \& Patterson RJ 2001 Association of galectin-1 and galectin-3 with Gemin 4 in complexes containing the SMN protein. Nucleic Acids Res 29 3595-3602.

Peppa M, Brem H, Ehrlich P, Zhang JG, Cai W, Li Z, Croitoru A, Thung S \& Vlassara H 2003 Adverse effects of dietary glycotoxins on wound healing in genetically diabetic mice. Diabetes $\mathbf{5 2}$ 2805-2813.

Perillo NL, Pace KE, Seilhamer JJ \& Baum LG 1995 Apoptosis of T cells mediated by galectin-1. Nature 378 736-739.

Perillo NL, Uittenbogaart CH, Nguyen JT \& Baum LG 1997 Galectin-1, an endogenous lectin produced by thymic epithelial cells, induces apoptosis of human thymocytes. Journal of Experimental Medicine 185 1851-1858.

Perone MJ, Bertera S, Tawadrous ZS, Shufesky WJ, Piganelli JD, Baum LG, Trucco M \& Morelli AE 2006 Dendritic cells expressing transgenic galectin-1 delay onset of autoimmune diabetes in mice. Journal of Immunology 177 5278-5289.

Poirier F \& Robertson EJ 1993 Normal development of mice carrying a null mutation in the gene encoding the L14 S-type lectin. Development 119 1229-1236.

del Pozo MA, Cabanas C, Montoya MC, Ager A, Sanchez-Mateos P \& Sanchez-Madrid F 1997 ICAMs redistributed by chemokines to cellular uropods as a mechanism for recruitment of T lymphocytes. J Cell Biol 137 493-508.

Pugliese G, Pricci F, Iacobini C, Leto G, Amadio L, Barsotti P, Frigeri L, Hsu DK, Vlassara H, Liu FT et al. 2001 Accelerated diabetic glomerulopathy in galectin-3/AGE receptor 3 knockout mice. FASEB Journal 15 2471-2479. 
Rabinovich GA, Iglesias MM, Modesti NM, Castagna LF, Wolfenstein-Todel C, Riera CM \& Sotomayor CE 1998 Activated rat macrophages produce a galectin-1-like protein that induces apoptosis of $\mathrm{T}$ cells: biochemical and functional characterization. Journal of Immunology $1604831-4840$.

Rabinovich GA, Ariel A, Hershkoviz R, Hirabayashi J, Kasai KI \& Lider O $1999 a$ Specific inhibition of T-cell adhesion to extracellular matrix and proinflammatory cytokine secretion by human recombinant galectin-1. Immunology 97 100-106.

Rabinovich GA, Daly G, Dreja H, Tailor H, Riera CM, Hirabayashi J \& Chernajovsky Y $1999 b$ Recombinant galectin-1 and its genetic delivery suppress collagen-induced arthritis via $\mathrm{T}$ cell apoptosis. Journal of Experimental Medicine 190 385-398.

Rabinovich GA, Sotomayor CE, Riera CM, Bianco I \& Correa SG 2000 Evidence of a role for galectin-1 in acute inflammation. European Journal of Immunology 30 1331-1339.

Rabinovich GA, Baum LG, Tinari N, Paganelli R, Natoli C, Liu FT \& Iacobelli S 2002 Galectins and their ligands: amplifiers, silencers or tuners of the inflammatory response? Trends Immunol 23 313-320.

Raz A \& Lotan R 1987 Endogenous galactoside-binding lectins: a new class of functional tumor cell surface molecules related to metastasis. Cancer Metastasis Rev 6 433-452.

Saegusa J, Hsu DK, Liu W, Kuwabara I, Kuwabara Y, Yu L \& Liu FT 2008 Galectin-3 protects keratinocytes from UVB-induced apoptosis by enhancing AKT activation and suppressing ERK activation. J Invest Dermatol 128 2403-2411.

Sano H, Hsu DK, Yu L, Apgar JR, Kuwabara I, Yamanaka T, Hirashima M \& Liu FT 2000 Human galectin-3 is a novel chemoattractant for monocytes and macrophages. Journal of Immunology 165 2156-2164.

Sano H, Hsu DK, Apgar JR, Yu L, Sharma BB, Kuwabara I, Izui S \& Liu FT 2003 Critical role of galectin-3 in phagocytosis by macrophages. J Clin Invest 112 389-397.

Santucci L, Fiorucci S, Cammilleri F, Servillo G, Federici B \& Morelli A 2000 Galectin-1 exerts immunomodulatory and protective effects on concanavalin A-induced hepatitis in mice. Hepatology 31 399-406.

Santucci L, Fiorucci S, Rubinstein N, Mencarelli A, Palazzetti B, Federici B, Rabinovich GA \& Morelli A 2003 Galectin-1 suppresses experimental colitis in mice. Gastroenterology 124 1381-1394.

Sato S, Ouellet N, Pelletier I, Simard M, Rancourt A \& Bergeron MG 2002 Role of galectin-3 as an adhesion molecule for neutrophil extravasation during streptococcal pneumonia. Journal of Immunology 168 1813-1822.

Saussez S, Decaestecker C, Mahillon V, Cludts S, Capouillez A, Chevalier D, Vet HK, Andre S, Toubeau G, Leroy X et al. 2008 Galectin-3 upregulation during tumor progression in head and neck cancer. Laryngoscope 118 $1583-1590$.

Scott K \& Weinberg C 2004 Galectin-1: a bifunctional regulator of cellular proliferation. Glycoconjugate Journal 19 467-477.

Seki M, Sakata KM, Oomizu S, Arikawa T, Sakata A, Ueno M, Nobumoto A, Niki T, Saita N, Ito K et al. 2007 Beneficial effect of galectin 9 on rheumatoid arthritis by induction of apoptosis of synovial fibroblasts. Arthritis Rheum 56 3968-3976.

Seki M, Oomizu S, Sakata KM, Sakata A, Arikawa T, Watanabe K, Ito K, Takeshita K, Niki T, Saita N et al. 2008 Galectin-9 suppresses the generation of Th17, promotes the induction of regulatory $\mathrm{T}$ cells, and regulates experimental autoimmune arthritis. Clin Immunol 127 78-88.

Serhan CN, Brain SD, Buckley CD, Gilroy DW, Haslett C, O'Neill LA, Perretti M, Rossi AG \& Wallace JL 2007 Resolution of inflammation: state of the art, definitions and terms. FASEB Journal 21 325-332.

Silva-Monteiro E, Reis Lorenzato L, Kenji Nihei O, Junqueira M, Rabinovich GA, Hsu DK, Liu FT, Savino W, Chammas R \& Villa-Verde DM 2007 Altered expression of galectin-3 induces cortical thymocyte depletion and premature exit of immature thymocytes during Trypanosoma cruzi infection. American Journal of Pathology 170 546-556.

Stillman BN, Hsu DK, Pang M, Brewer CF, Johnson P, Liu FT \& Baum LG 2006 Galectin-3 and galectin-1 bind distinct cell surface glycoprotein receptors to induce $\mathrm{T}$ cell death. Journal of Immunology 176 778-789.
Stitt AW, McGoldrick C, Rice-McCaldin A, McCance DR, Glenn JV, Hsu DK, Liu FT, Thorpe SR \& Gardiner TA 2005 Impaired retinal angiogenesis in diabetes: role of advanced glycation end products and galectin-3. Diabetes 54 785-794.

Stowell SR, Qian Y, Karmakar S, Koyama NS, Dias-Baruffi M, Leffler H, McEver RP \& Cummings RD 2008 Differential roles of galectin-1 and galectin-3 in regulating leukocyte viability and cytokine secretion. Journal of Immunology 180 3091-3102.

Streuli C 1999 Extracellular matrix remodelling and cellular differentiation. Curr Opin Cell Biol 11 634-640.

Suzuki Y, Inoue T, Yoshimaru T \& Ra C 2008 Galectin-3 but not galectin-1 induces mast cell death by oxidative stress and mitochondrial permeability transition. Biochemica and Biophysica Acta 1783 924-934.

Symons A, Cooper DN \& Barclay AN 2000 Characterization of the interaction between galectin-1 and lymphocyte glycoproteins CD45 and Thy-1. Glycobiology 10 559-563.

Taipale J \& Keski-Oja J 1997 Growth factors in the extracellular matrix. FASEB Journal 11 51-59.

Than NG, Erez O, Wildman DE, Tarca AL, Edwin SS, Abbas A, Hotra J, Kusanovic JP, Gotsch F, Hassan SS et al. 2008 Severe preeclampsia is characterized by increased placental expression of galectin-1. J Matern Fetal Neonatal Med 21 429-442.

Thijssen VL, Postel R, Brandwijk RJ, Dings RP, Nesmelova I, Satijn S, Verhofstad N, Nakabeppu Y, Baum LG, Bakkers J et al. 2006 Galectin-1 is essential in tumor angiogenesis and is a target for antiangiogenesis therapy. PNAS 103 15975-15980.

Thijssen VL, Poirier F, Baum LG \& Griffioen AW 2007 Galectins in the tumor endothelium: opportunities for combined cancer therapy. Blood $\mathbf{1 1 0}$ 2819-2827.

Toscano MA, Commodaro AG, Ilarregui JM, Bianco GA, Liberman A, Serra HM, Hirabayashi J, Rizzo LV \& Rabinovich GA 2006 Galectin-1 suppresses autoimmune retinal disease by promoting concomitant Th2- and T regulatory-mediated anti-inflammatory responses. Journal of Immunology 176 6323-6332.

Toscano MA, Bianco GA, Ilarregui JM, Croci DO, Correale J, Hernandez JD, Zwirner NW, Poirier F, Riley EM, Baum LG et al. 2007 Differential glycosylation of TH1, TH2 and TH-17 effector cells selectively regulates susceptibility to cell death. Nat Immunol 8 825-834.

Truong MJ, Gruart V, Kusnierz JP, Papin JP, Loiseau S, Capron A \& Capron M 1993 Human neutrophils express immunoglobulin E (IgE)binding proteins (Mac-2/epsilon $\mathrm{BP}$ ) of the S-type lectin family: role in IgE-dependent activation. Journal of Experimental Medicine 177 243-248.

Tsuboi Y, Abe H, Nakagawa R, Oomizu S, Watanabe K, Nishi N, Nakamura T, Yamauchi A \& Hirashima M 2007 Galectin-9 protects mice from the Shwartzman reaction by attracting prostaglandin E2-producing polymorphonuclear leukocytes. Clin Immunol 124 221-233.

Tsuchiyama Y, Wada J, Zhang H, Morita Y, Hiragushi K, Hida K, Shikata K, Yamamura M, Kanwar YS \& Makino H 2000 Efficacy of galectins in the amelioration of nephrotoxic serum nephritis in Wistar Kyoto rats. Kidney Int 58 1941-1952.

Vlassara H, Li YM, Imani F, Wojciechowicz D, Yang Z, Liu FT \& Cerami A 1995 Identification of galectin-3 as a high-affinity binding protein for advanced glycation end products (AGE): a new member of the AGE-receptor complex. Mol Med 1 634-646.

Vyakarnam A, Dagher SF, Wang JL \& Patterson RJ 1997 Evidence for a role for galectin-1 in pre-mRNA splicing. Mol Cell Biol 17 $4730-4737$.

Wada J, Ota K, Kumar A, Wallner EI \& Kanwar YS 1997 Developmental regulation, expression, and apoptotic potential of galectin-9, a betagalactoside binding lectin. J Clin Invest 99 2452-2461.

Walzel H, Schulz U, Neels P \& Brock J 1999 Galectin-1, a natural ligand for the receptor-type protein tyrosine phosphatase CD45. Immunology Letters 67 193-202.

Wang JL, Gray RM, Haudek KC \& Patterson RJ 2004 Nucleocytoplasmic lectins. Biochemica and Biophysica Acta 1673 75-93. 
Wang F, He W, Zhou H, Yuan J, Wu K, Xu L \& Chen ZK 2007 The Tim-3 ligand galectin-9 negatively regulates CD8 + alloreactive $\mathrm{T}$ cell and prolongs survival of skin graft. Cell Immunol 250 68-74.

Yamamoto H, Kashio Y, Shoji H, Shinonaga R, Yoshimura T, Nishi N, Nabe T, Nakamura T, Kohno S \& Hirashima M 2007 Involvement of galectin-9 in guinea pig allergic airway inflammation. Int Arch Allergy Immunol 143 (Supplement 1) 95-105.

Yamaoka A, Kuwabara I, Frigeri LG \& Liu FTA 1995 A human lectin, galectin-3 (epsilon bp/Mac-2), stimulates superoxide production by neutrophils. Journal of Immunology 154 3479-3487.

Yang RY, Hsu DK \& Liu FT 1996 Expression of galectin-3 modulates T-cell growth and apoptosis. PNAS 93 6737-6742.

Yang RY, Rabinovich GA \& Liu FT 2008 Galectins: structure, function and therapeutic potential. Expert Rev Mol Med 10 e17.

Yu F, Finley RL Jr, Raz A \& Kim 2002 Galectin-3 translocates to the perinuclear membranes and inhibits cytochrome $\mathrm{c}$ release from the mitochondria. A role for synexin in galectin-3 translocation. Journal of Biological Chemistry 277 15819-15827.

Yu LG, Andrews N, Zhao Q, McKean D, Williams JF, Connor LJ, Gerasimenko OV, Hilkens J, Hirabayashi J \& Kasai K 2007 Galectin-3 interaction with Thomsen-Friedenreich disaccharide on cancer-associated MUC1 causes increased cancer cell endothelial adhesion. Journal of Biological Chemistry 282 773-781.

Zhou Q \& Cummings RD 1993 L-14, lectin recognition of laminin and its promotion of in vitro cell adhesion. Arch Biochem Biophys 300 6-17.

Zhu C, Anderson AC, Schubart A, Xiong H, Imitola J, Khoury SJ, Zheng XX, Strom TB \& Kuchroo VK 2005 The Tim-3 ligand galectin-9 negatively regulates $\mathrm{T}$ helper type 1 immunity. Nat Immunol 6 $1245-1252$.

Zuberi RI, Hsu DK, Kalayci O, Chen HY, Sheldon HK, Yu L, Apgar JR, Kawakami T, Lilly CM \& Liu FT 2004 Critical role for galectin-3 in airway inflammation and bronchial hyperresponsiveness in a murine model of asthma. American Journal of Pathology 165 2045-2053.

Received in final form 14 January 2009

Accepted 20 January 2009

Made available online as an Accepted Preprint 20 January 2009 